\title{
Macrobenthic communities on the continental shelf of Côte-d'Ivoire. Seasonal and diel cycles in relation to hydroclimate
}

\author{
Pierre LE LOEUFF * André INTÈS \\ Centre IRD de Bretagne, BP 70, 29280 Plouzané
}

(Received 12 November 1998, revised 19 July 1999, accepted 20 July 1999)

\begin{abstract}
Benthic communities of the shrimp (Penaeus notialis) grounds off Grand-Bassam, Côte-d'Ivoire, exhibit distinct variations, correlated to annual changes in hydroclimate, characterized by warm and cold (upwelling) seasons. These changes appear to be the result of the well-defined reproduction periods of many short-living benthic species, as clearly shown by the peaks of abundance in the samples, at different times of the year, but quite often at the end of the cold and the beginning of the warm seasons (September-November). Many species show marked diel rhythms, either diurnal (pagurids, brachyurans) or nocturnal (macrurans, brachyurans, molluscs), so that the species composition displays distinct differences between day and night samples (February 1970 survey). This diel rhythm can be disturbed at the beginning of the rainy season (May 1969 survey) by the passing of turbid water lenses over the bottom, drifted from the Ébrié lagoon mouth, close to the study site. The diel cycles of some species (stomatopods) appear to be completely altered by the reduced light intensity near the bottom whereas others (some pagurids and brachyurans) are practically unaffected: they seem to be governed by internal physiological mechanisms or they need only a very low threshold of light to maintain their rhythms. So the differences between day and night samples are appreciably reduced, as shown by Correspondence Analysis. (C) 1999 Ifremer / CNRS / IRD / Ėditions scientifiques et médicales Elsevier SAS
\end{abstract}

\section{benthic fauna / Gulf of Guinea / seasonal cycle / diel cycle / perturbation}

Résumé - Communautés macrobenthiques du plateau continental ivoirien : cycles saisonnier et nycthéméral en relation avec les variations hydroclimatiques. Les peuplements benthiques des fonds à pénéides (Penaeus notialis) au large de Grand-Bassam (Côte-d'Ivoire) présentent de nettes variations directement lićcs à celles de l'hydroclimat, caractérisé par la succession de saisons chaudes et froides (upwellings). De nombreuses espèces benthiques, à courte durée de vie, ont en effet des périodes de reproduction bien définies qui se traduisent par des pics d'abondance dans les récoltes, à différentes époques de l'année selon les espèces mais, le plus souvent, en fin de saison froide-début de saison chaude (septembre-novembre). De nombreuses espèces benthiques ont des rythmes nycthéméraux très accusés; leur activité est diurne (la plupart des pagures, certains brachyoures) ou nocturne (de nombreux macroures et brachyoures, quelques mollusques). De ce fait, les récoltes de jour se différencient nettement des récoltes de nuit (observations au cours de la campagne de février 1970). Il arrive cependant (campagne de mai 1969) que les rythmes jour/nuit soient perturbés, vraisemblablement par le passage de lentilles d'eau turbide sur les fonds en début de saison des pluies. Ces eaux sont chargées de matériel particulaire, minéral et organique, provenant de la lagune Ébrié dont le débouché est proche du site d'étude, et où se produit alors un bloom de phytoplancton ; la différence entre les éclairements régnant près du fond durant le jour et la nuit serait ainsi très atténuée. Le cycle nycthéméral de certaines espèces apparaît complètement altéré (stomatopodes), tandis qu'il demeure pratiquement inchangé chez d'autres (certains pagures et brachyoures), moins affectées par les variations d'intensité lumineuse : leurs rythmes vitaux seraient plutôt réglés par des processus internes ou leur main-

\footnotetext{
${ }^{*}$ Correspondence and reprints: leloeuff@ird.fr
} 
tien ne nécessiterait que très peu de lumière. Ce phénomène est sensible quand on considère l'ensemble du peuplement, les différences entre récoltes de jour et de nuit se réduisant de façon notable, comme le mettent en évidence les résultats des analyses factorielles. (C) 1999 Ifremer / CNRS / IRD / Éditions scientifiques et médicales Elsevier SAS

faune benthique / golfe de Guinée / cycle saisonnier / cycle circadien / perturbation

\section{INTRODUCTION}

In the years 1969 and 1970 , the peneid shrimp, Penaeus notialis, began to be intensively fished along the Côted'Ivoire coast [37]. Since this time, the shrimp fishery has affected by a lot of variations [24]. In 1970-1971, about twenty shrimp trawlers landed in Abidjan 600-700 $\mathrm{t} \mathrm{yr}^{-1}$ of peneids. Then, the catches quickly decreased and remained steady around $400-500$ tons until 1979; at the same time the number of vessels also decreased to six from 1976 until 1980 when production fell to 260 tons. This drop in catches led the shrimp trawlers to leave the Côte-d'Ivoire. In 1981-1982 there was no exploitation of the Ivorian shrimp grounds. It resumed in 1983 and progressively the fishing effort increased: nine shrimp vessels were working in 1989. Until 1990 the catch was about $400 \mathrm{t} \mathrm{yr}^{-1}$. But, in 1991, another fall of the catch (180 l) was observed and the production then remained at this level with four vessels regularly exploiting the peneid grounds.

At the very beginning of the shrimp fishery (1969), the Centre de Recherches Océanographiques at Abidjan undertook exploratory trawling to study the biology and the dynamics of the exploited populations of this shrimp $[11,24]$. Special attention was given to the seasonal evolution and the diel cycle of this peneid species, these biological features being particularly important for the fishing strategy. Exploratory surveys were carried out on the main fishing ground for this species, the Grand-Bassam area (figure 1). Species of the benthic invertebrate fauna collected during these exploratory surveys were identificd and their abundanee recorded.

Our knowledge of the tropical benthic ecosystems (endofauna, trawlable epifauna) remains very limited. The few studies carried out on trawling sample data, in the Gulf of Mexico [16, 17] and in Australia [26] mostly deal with
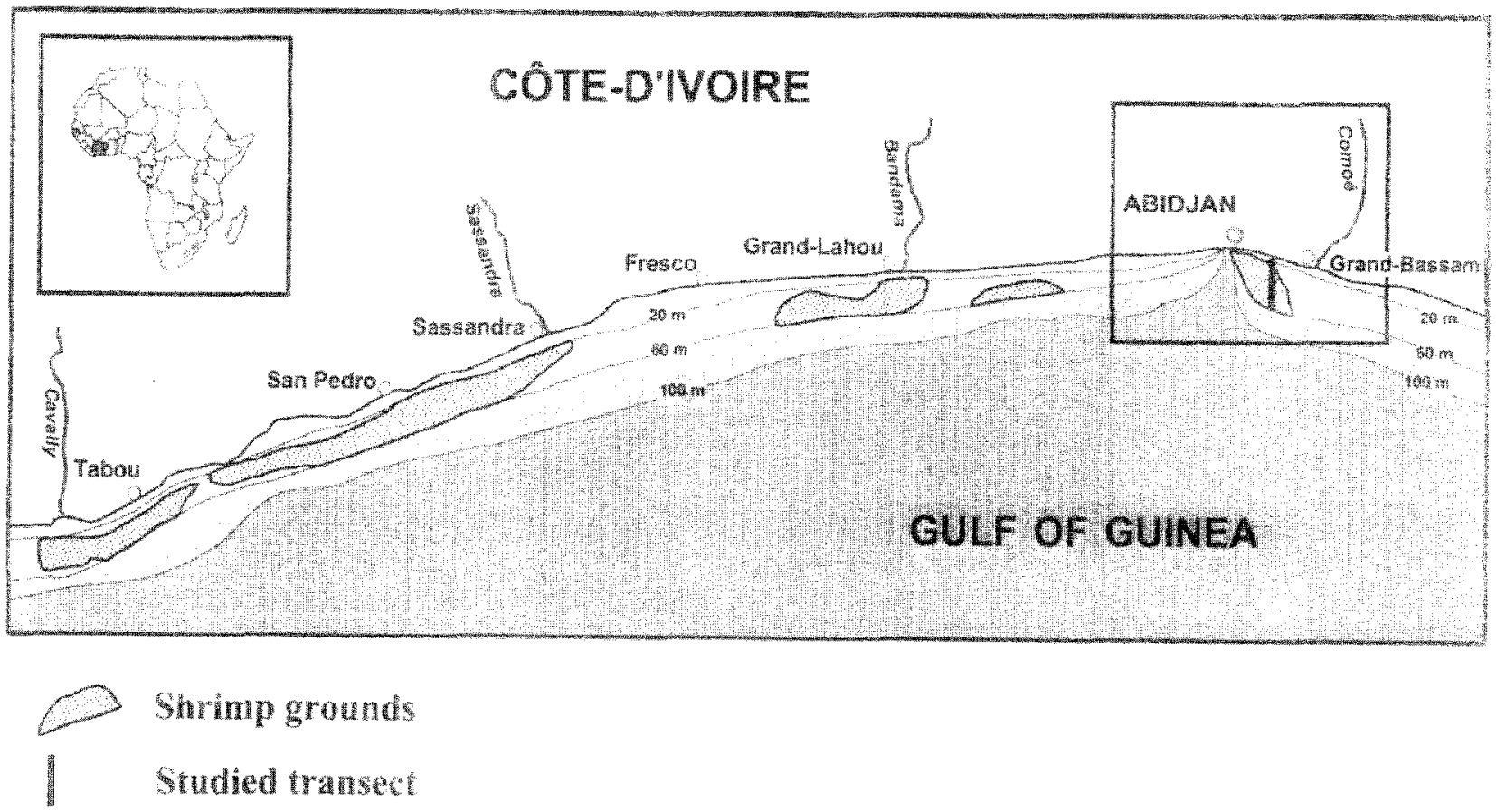

Figure 1. The continental shelf of the Côte-d'Tvoire: shrimp grounds, studied transect and main rivers. 

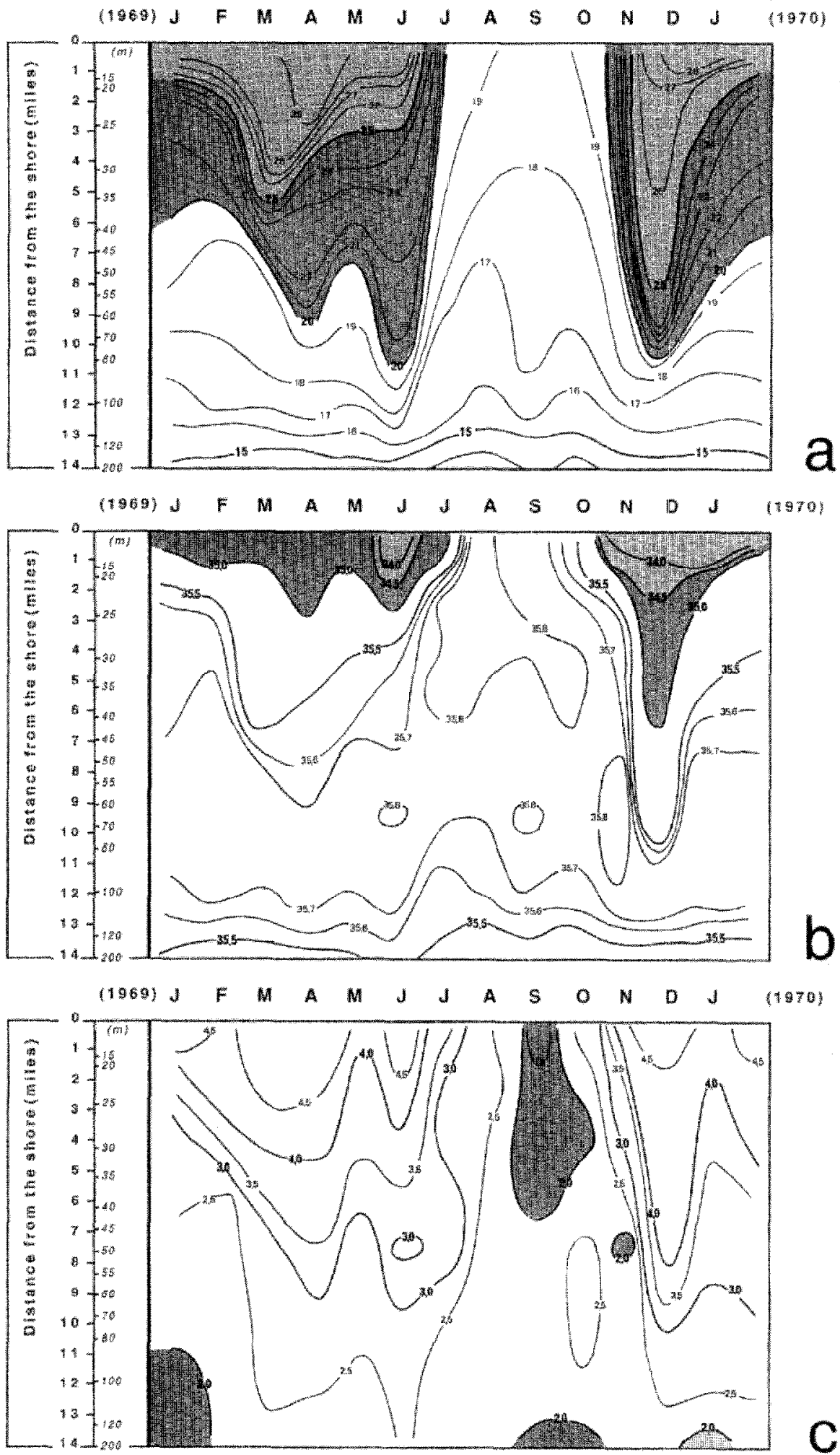

Figure 2. Hydrological conditions at the bottom of the continental shelf off Grand-Bassam (Côte-d'Ivoire) from January 1969 to January 1970. (a) temperature $\left({ }^{\circ} \mathrm{C}\right)$, (b) salinity, (c) dissolved oxygen $\left(\mathrm{mL} \mathrm{L}^{-1}\right)$. Depths shown on the scale of distances from the shore are only markers. 
the assessment of the fauna and the description of the communities. For the tropical Atlantic coast of $\Lambda$ frica, only studies in Côte-d'Ivoire [21, 23] and Guinea [20] have been published. The information available on seasonal and diel cycles, as presented and discussed in this paper, is also very limited, as seen below.

\section{MATERIAL AND METHODS}

Monthly cruises were carried out between January 1969 and January 1970 (table I) to study the seasonal variations in the Penaeus notialis population. Trawl hauls were performed on the continental shelf at depths of 25 , $30,35,40,45,50,55,60 \mathrm{~m}$ along a north-south transect $\left(3^{\circ} 49.5^{\prime} \mathrm{W}\right)$. The trawling apparatus was a semi-balloon Floridian shrimp trawl, $12 \mathrm{~m}$ headrope, $15 \mathrm{~m}$ footrope, $28 \mathrm{~mm}$ codend mesh (measured with knots stretched), maximum height of the trawl aperture: $3 \mathrm{~m}$ (estimation). The hauls lasted one hour and the trawling distance was about 3 nautical miles. Hydrological data (temperature, salinity, dissolved oxygen) were also collected on the bottom at every trawling station and at 15, 20, 70, 80, 100, $200 \mathrm{~m}$ depth to cover the whole continental shelf.

Besides these monthly surveys, data were obtained on diel variations in the Penaeus notialis ground benthic community. For this purpose, two additional cruises (2024 May 1969 and 6-10 February 1970) were made at $45 \mathrm{~m}$ depth, in the centre of the peneid biotope [11, 24]:
Table $\mathbb{I}$. Cruise dates allong the Grand-Bassam transect $\left(3^{\circ} 49.5^{\prime} \mathrm{W}\right)$

\begin{tabular}{lccc}
\hline Cruises & Dates & Cruises & Dates \\
\hline 1 & $14-15 / 1 / 1969$ & 8 & $1-2 / 8 / 1969$ \\
2 & $11-12 / 2 / 1969$ & 9 & $26-27 / 8 / 1969$ \\
3 & $11-12 / 3 / 1969$ & 10 & $24-25 / 9 / 1969$ \\
4 & $10-11 / 4 / 1969$ & 11 & $21-22 / 10 / 1969$ \\
5 & $6-7 / 5 / 1969$ & 12 & $18-19 / 11 / 1969$ \\
6 & $3-4 / 6 / 1969$ & 13 & $16-17 / 12 / 1969$ \\
7 & $1-2 / 7 / 1969$ & 14 & $14-15 / 1 / 1970$ \\
\hline
\end{tabular}

trawl samples were taken continuously, day and night, during the course of four complete diel cycles and the beginning of a fifth. The sampling apparatus was the same but the hauls lasted only 45 minutes. A total of 39 hauls were obtained during the May cruise and 48 hauls during the February cruise. During every cruise, the total catch was handled on board after each haul: identification of the species (well known as a result of many previous surveys) and counting of all the collected specimens.

Hydrological data were processed in a classical way (drawing of isolines on the bottom over the study year), and through Principal Component Analysis (PCA). Graphs were drawn showing the distribution of abundance throughout the year for the samples of several significant species. Faunal data of the annual cycle study were processed through a Correspondence Analysis (COA) dealing with the marginal distribution of the abundance of species in each cruise (i.e. total number of specimens of each species caught during a cruise). From May

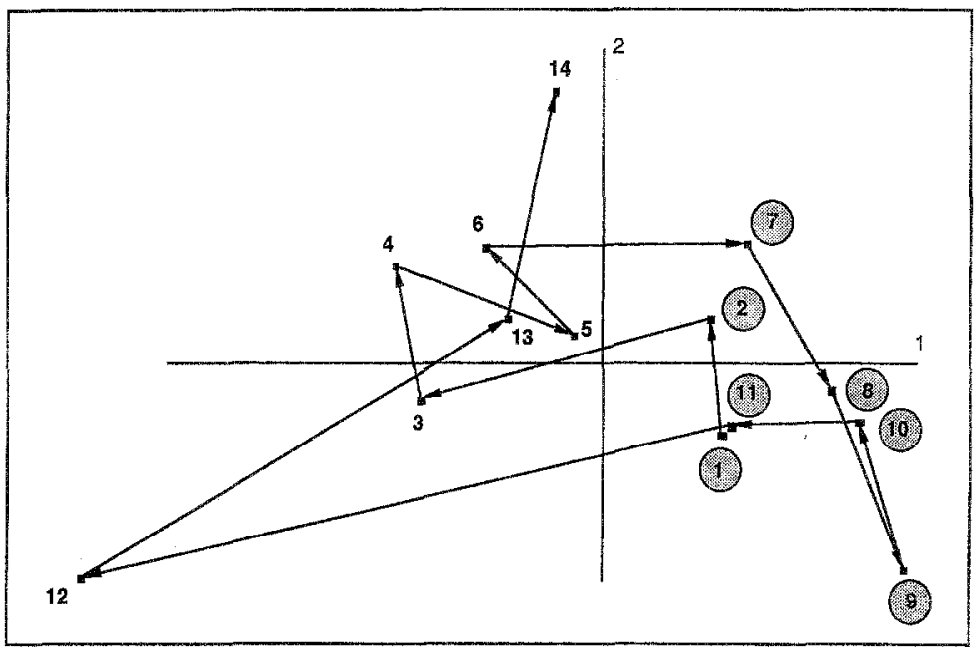

Figure 3. Hydroclimatic cycle from January 1969 to January 1970 (cruises 1 to 14) on the bottom of the continental shelf off Grand-Bassam. Results from a Principal Component Analysis (PCA) on temperature, salinity and dissolved oxygen, in barycentric representation (matrix $108 \times 3 ; \%$ total variance: axis 1: $90.0 \%$, axis $2: 7.0 \%$ ). The data points for the cold seasons are shown in shaded circles. 
and February cruise samples, graphs of the diel cycles abundance of some characteristic species were drawn; for each day and night period, the mean values of the species number, total abundance, Shannon's diversity and evenness were plotted over the circadian cycles. The biological data (abundance of the species) were also processed through several COA dealing on one hand with the general matrix species/data, on the other hand with the mean distributions of the abundance of species, during successive day and night hauls, each for a period of 3 hours.

\section{RESULTS}

\subsection{Seasonal data}

\subsubsection{The hydroclimatic cycle}

The hydroclimatic conditions during the study period were characterized by upwelling of cold water in January-February, minor cold season, and again in JulyOctoher, major cold season (figure $2 a$ ). During the latter there was a reduction of the oxygen content of the bottom waters (figure $2 c$ ), caused by oxidation of organic matter, the production of which is maximum at that time. The two cold seasons alternated with two warm periods: the first, from March to June, marked by strong rainfalls in June (wet season) and a reduction in salinity (figure $2 b$ ) in shallow waters; the second, from November to January, with a more pronounced reduction in salinity, associated to a high freshwater advection in November from the Bandama and Comoé rivers (rivers with Sahelo-Soudanian regime). A synopsis of the hydroclimatic cycle for the year 1969 is given (figure 3), based on PCA carried out on temperature, salinity and dissolved oxygen of the bottom waters, from 25 to $60 \mathrm{~m}$ depth, during the cruises (weighted representation of the observation points for each of the cruises, noted 1 to 14). The data points for the cold scasons become distinctly separate from those of the warm seasons; the data point 12 (November) corresponds to the period of high river discharge and hence is located away of the other warm season points.

\subsubsection{The seasonal cycle of the benthic fauna}

Macrofauna species collected by the shrimp trawls along the transect (annex I) consisted mostly of cnidarians (sedentary epifauna), crustaceans, molluscs and echinoderms (mobile epifauna, which can sometimes be buried or liv- ing in burrows, or superficial endofauna, caught by the trawl, the footrope of which being chained and scraping the bottom). In terms of abundance, the crustaceans (some stomatopods, but mostly decapods), with 59 species and 17279 specimens out of a total of 22488 , were distinctly dominant.

Month-to-month changes in the abundance of the most commonly occurring species (figure 4) showed several seasonal patterns. Thus, the gastropod Murex varius and the pagurid Diogenes ovatus were especially abundant in the minor cold season, the scyllarids Scyllarus caparti and Scyllarus posteli at the beginning of the warm season (March) and at the beginning of the major cold season (July-August). Catches of the brachyurans Portunus inaequalis and Callinectes pallidus showed a peak at the heginning of the major cold season (Iuly-August); the urchin Schizaster edwardsi in the middle of this period (August-September). The brachyuran Macropipus rugosus, the peneid Sicyonia galeata, the opisthobranch Pleurobranchaea gela, the bivalve Lissochlamys exoticus, the alcyonarian Metalcyonium violaceum had a peak of abundance during the course of the second part of the warm season (November-December). This last form of seasonal abundance is common to many species.

Time-to-time changes in abundance of species followed a seasonal cycle as indicated by COA in which each of the four hydroclimatic periods is clearly identified (figure 5): faunistic changes in the communities match with the physical environment changes.

\section{2. The diel cycles in the two studied periods on the shrimp (Penaeus notialis) fishing grounds}

\subsubsection{Hydroclimatology}

The hydrological conditions at $45 \mathrm{~m}$ depth during the two study periods were both typical of a warm season situation: temperature 20.4 (May, 1969) and $22.5^{\circ} \mathrm{C}$ (February, 1970); salinity 35.7 and 35.5; dissolved oxygen 2.9 and $3.8 \mathrm{ml} \mathrm{L}^{-1}$. The beginning of the minor cold season generally varies from year to year and unlike 1969, the minor cold season in Côte-d'Ivoire in 1970 began only in March.

Nevertheless surface observations at a reference station not far from the Grand-Bassam transect $\left(4^{\circ} 02^{\prime} \mathrm{W}\right.$, at $20 \mathrm{~m}$ bottom depth) showed that the salinity fell from 34.8 (2 May 1969) to 31.7 (27 May 1969), while, from 31 January 1970 to 14 February 1970 , salinity remained 

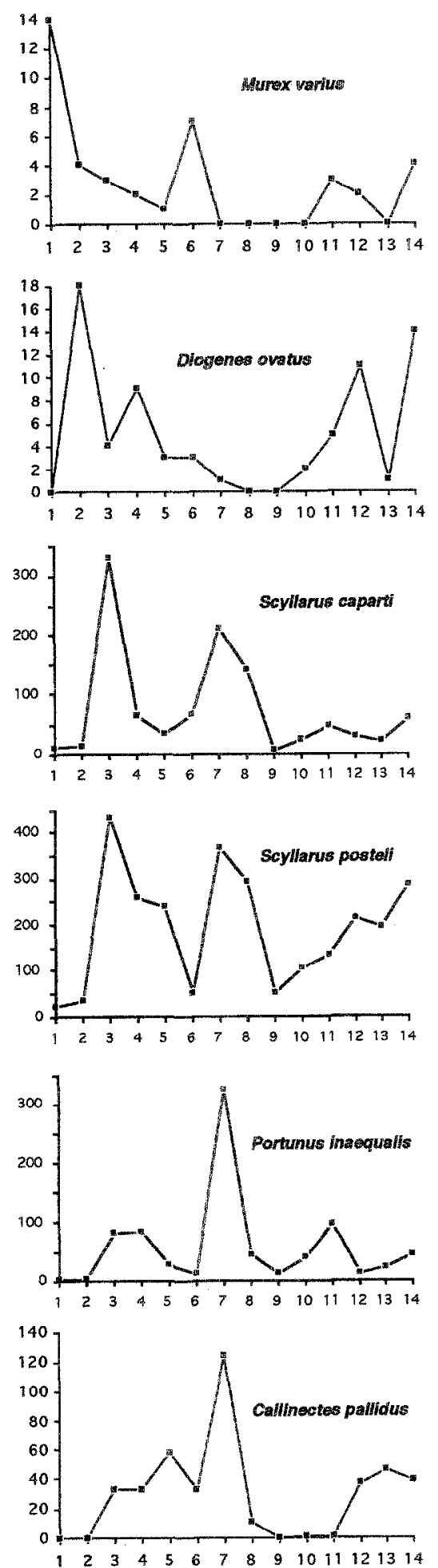
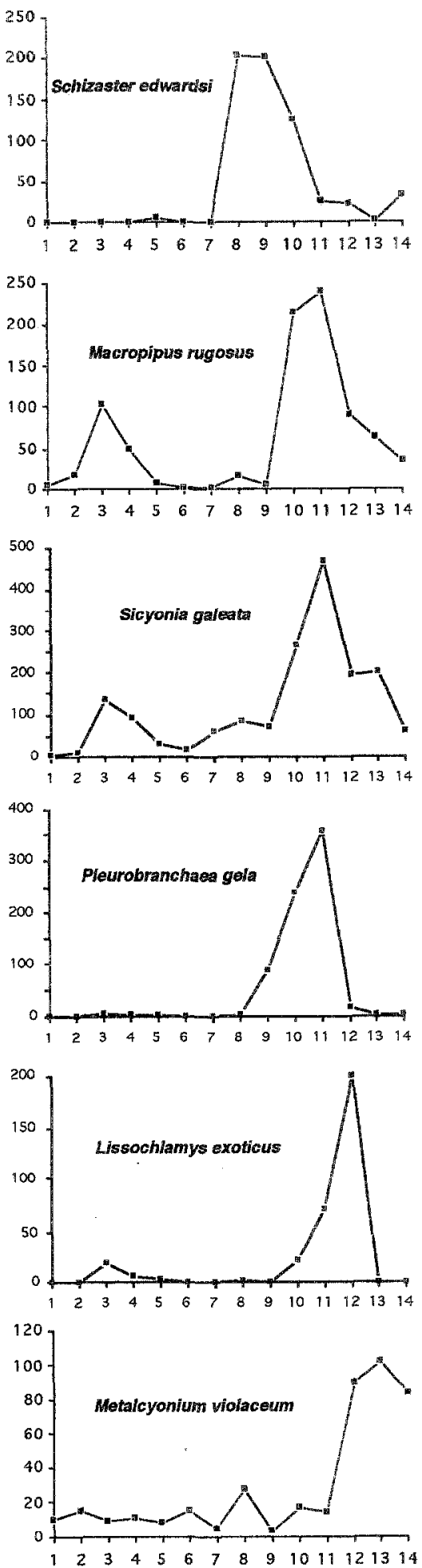

Figure 4. Examples of variations in the catch per cruise (total on all the transect hauls) of some species showing peaks of abundance at welldefined periods of the year. 


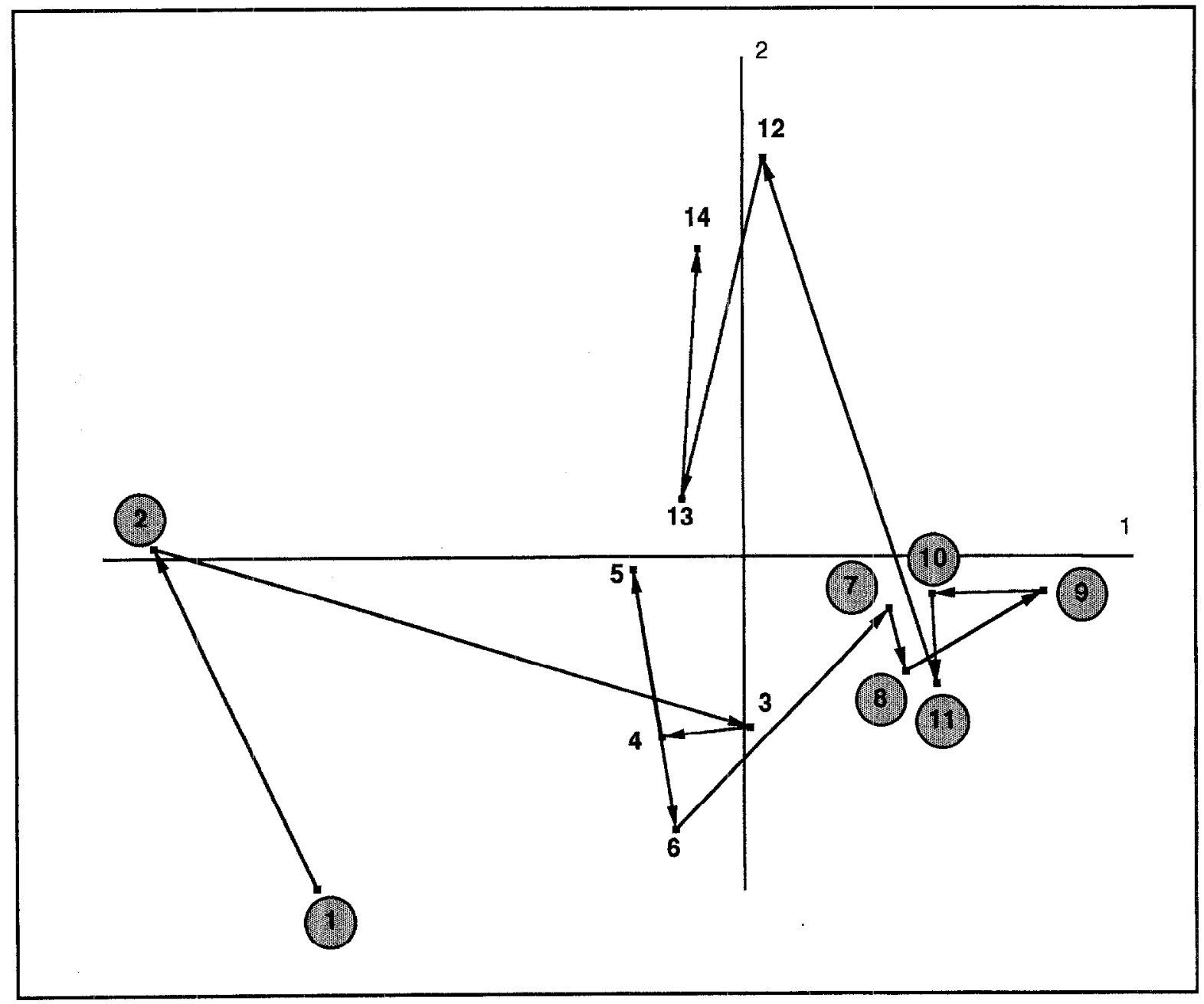

Figure 5. Changes in the faunal composition of the benthic communities from January 1969 to January 1970 (cruises 1 to 14) on the continental shelf off Grand-Bassam. Results of a Correspondence Analysis (COA) on the marginal distribution of the number of individuals of each species in each cruise (matrix $104 \times 14 ; \%$ total variance, axis 1: $18.7 \%$, axis 2: $15.1 \%$ ). The data points for the cold seasons are shown in shaded circles.

almost steady at 34.6 [33]. In 1969, the wet season, which usually peaks in June in the littoral of the Côte-d'Ivoire, had begun by late April-early May: some heavy rainfall had already occurred in the Abidjan and Grand-Bassam region [7] prior to the May cruise dates (figure 6). Conversely, during the weeks preceding the February 1970 cruise, rainfall values were quite low.

\subsubsection{The fauna nyctimeral rhythms}

The community associated with the shrimp fishing grounds is characterized by the scyllarids Scyllarus caparti, Scyllarus posteli, the peneid Sicyonia galeata, the pagurid Pagurus cuanensis, the brachyurans
Medorippe lanata, Machaerus oxyacantha, the gastropods Architectonica nobilis, Sigaretus concavus, Distorsio ridens, Metula cumingi, Lathyrus filosus, Cancellaria cancellata, Clavatuia muricata and the bivalve Pitar elata [23]. All these species and the others collected by the shrimp trawl on the $45 \mathrm{~m}$ depth grounds off GrandBassam (including the peneids Sicyonia galeata, Solenocera africana and the carid Pontocaris cataphracta) live on or very near the bottom and do not exhibit vertical migrations (Annexes 2 and 3). They can be classified into three behavioural groups [23]. The first includes diurnally active species (majority of pagurids, some brachyurans, some asterids), the second, nocturnally active species (stomatopods, shrimps, a majority of 


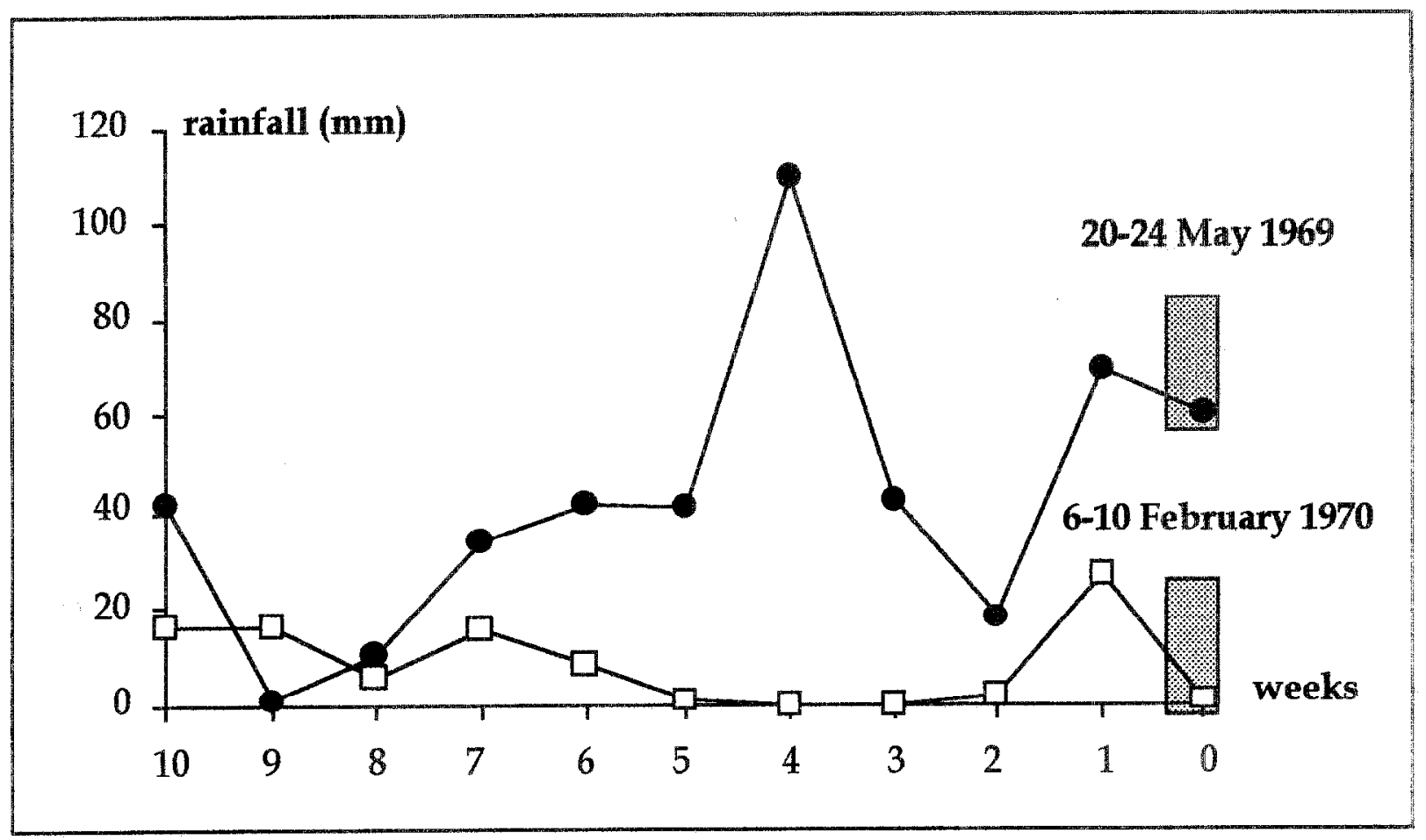

Figure 6. Rainfall in the area of Abijan and Grand-Bassam in the weeks preceding the 20-24 May 1969 and the 6-10 February 1970 cruises.

brachyurans, some gastropods), and the third, those species that are insensitive to day/night alternations (gastropods, echinids). This was the situation observed during the Fehruary 1970 cruise. On the other hand, a different situation prevailed during the May 1969 cruise: while the behaviour of some invertebrates such as the pagurid Paguristes mauritanicus (diurnal) or the brachyuran $\mathrm{Mac}$ ropipus rugosus (nocturnal) remained essentially unaltered (figure 7), a number of other species exhibited more or less altered nyctimeral rhythms, becoming insensitive to the day/night succession, or even quasi-diurnal, notably the very nocturnal stomatopods Squilla cadenati and Squilla mantis especially during the second and third day of the cruise (figure 7).

The structural parameters of the community (number of species, abundance, Shannon's diversity and evenness) fluctuated between day and night samples. In February 1970 , the number of species (figure $8 a$ ) and the abundance (figure $8 b$ ) values were systematically higher at night than during the day, whereas the reverse pattern occurred for diversity (figure $8 c$ ) and evenness (figure 8d). Conversely, in May 1969, the number of species was always much higher during the day than in the night, but showed a decreasing trend from the beginning to the end of the study period. The abundance of individuals was more irregular than in February, with a strong decrease from the fourth day onwards. The diversity and evenness indices tended to have lower values from the second to the third night; but, as a consequence of the low numbers of organisms in the collections, the highest evenness values were obtained on the fourth day.

The COA dealing with the faunal data of the two cruises (figure 9) shows that in both cases the composition of the day hauls differed from that of the night hauls. This difference was much more marked for the February cruise data. A direct comparison of the data of February and May in another COA carried out on the successive day and night mean data (figure 10), shows evidence for a deregulation of the nycthemeral rhythms of the fauna in May compared to February. In fact, during the February cruise, the faunal composition of the day and night hauls, respectively, remained almost identical over the sampling period, day and night samples being distinctly separate. In contrast, during the May cruise, the faunal composition of the second and third days' collections became closer to those of the night collections. In addition, the difference in the position of the data points between the May and the February cruises may reflect the 


$$
\begin{aligned}
& D=\text { Day } \\
& N=\text { Night }
\end{aligned}
$$

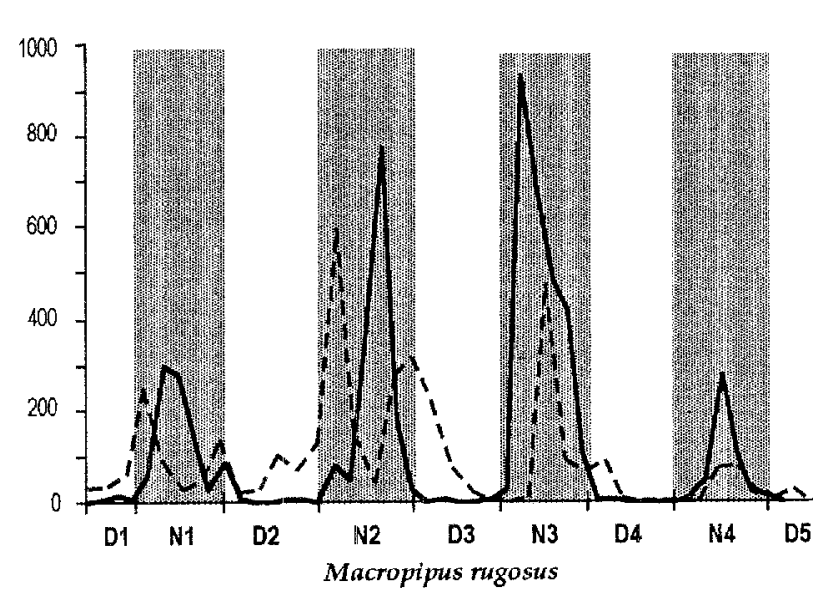

Mann-Whitney test results:

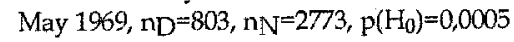

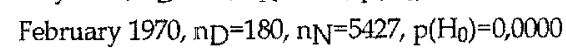

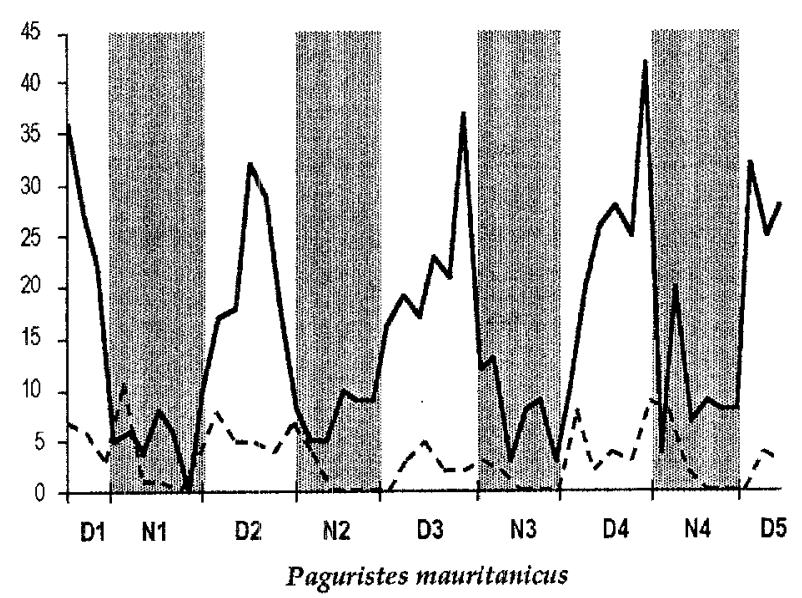

Mann-Whitney test results:

May 1969, $\mathrm{nD}^{-51,} \mathrm{nN}=11, \mathrm{p}\left(\mathrm{H}_{0}\right)=0,0001$.

February $1970, \mathrm{nD}=593, \mathrm{nN}_{\mathrm{N}}=164 \mathrm{p}\left(\mathrm{H}_{0}\right)=0,0000$
February 1970

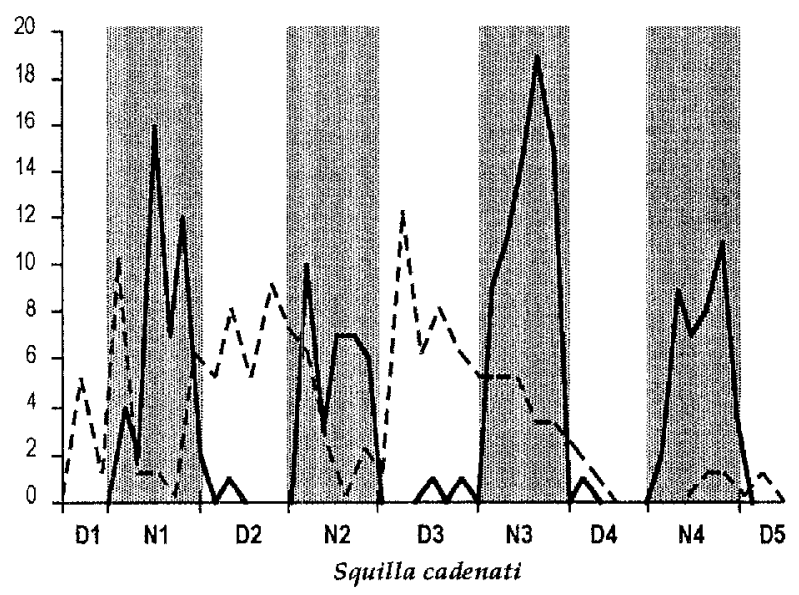

Mann-Whitney test results:

May 1969, $\mathrm{nD}=83, \mathrm{nN}_{\mathrm{N}}=45, \mathrm{p}\left(\mathrm{H}_{0}\right)=0.1366$

February $1970, \mathrm{nD}^{=2,} \mathrm{nN}=478, \mathrm{p}\left(\mathrm{H}_{0}\right)=0,0000$

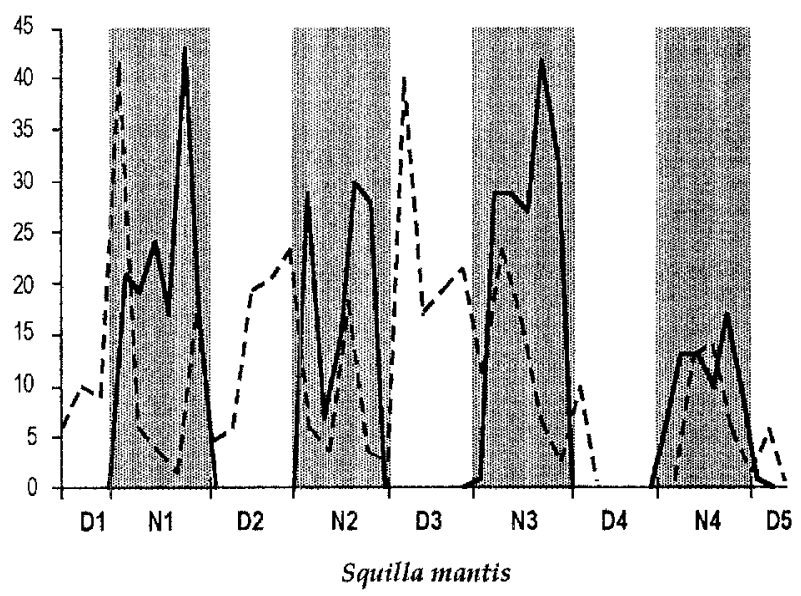

Mann-Whitney test results:

May 1969, $\mathrm{nD}^{-214, \mathrm{nN}^{-16}}$ - $\mathrm{p}\left(\mathrm{H}_{0}\right)=0.3316$

February $1970, \mathrm{nD}^{=4}, \mathrm{nN}=186, \mathrm{p}\left(\mathrm{H}_{0}\right)=0,0000$

Figure 7. Some examples of nyctimeral rhythms (number of individuals) on the $45 \mathrm{~m}$ depth bottom off Grand-Bassam: nocturnal (the brachyuran Macropipus rugosus), diurnal (the pagurid Paguristes mauritanicus), both little affected by variations in environmental conditions (light penetration to the bottom disturbed by turbid waters inputs in May); nocturnal in normal conditions but highly perturbed by these events in May (the stomatopods Squilla cadenati and Squilla mantis). For each of these species, highly significant differences are found between night and day distributions (Mann-Whitney test) except both Squilla distributions in May where no significant difference was observed.

seasonal cycle fluctuations of the fauna, as described earlier.

The circadian cycles, when examined on the basis of successive 3 hour sections, do not show any substantial difference between the two cruises (figure 11), but the night variations of the fauna are stronger than the day variations in both periods.

\section{DISCUSSION}

\subsection{The seasonal cycle}

As seen by changes in abundances of the most common species (figure 4), many of them showed one peak, and several two peaks of abundance at different times of the 


$$
\begin{aligned}
& D=\text { Day } \\
& N=\text { Night }
\end{aligned}
$$

(s)

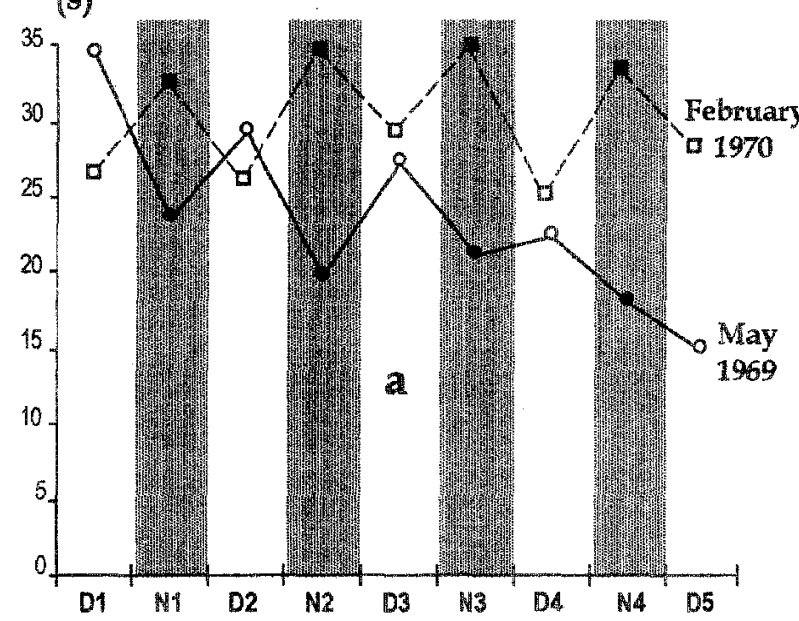

$\left(\mathrm{H}^{\prime}\right)$

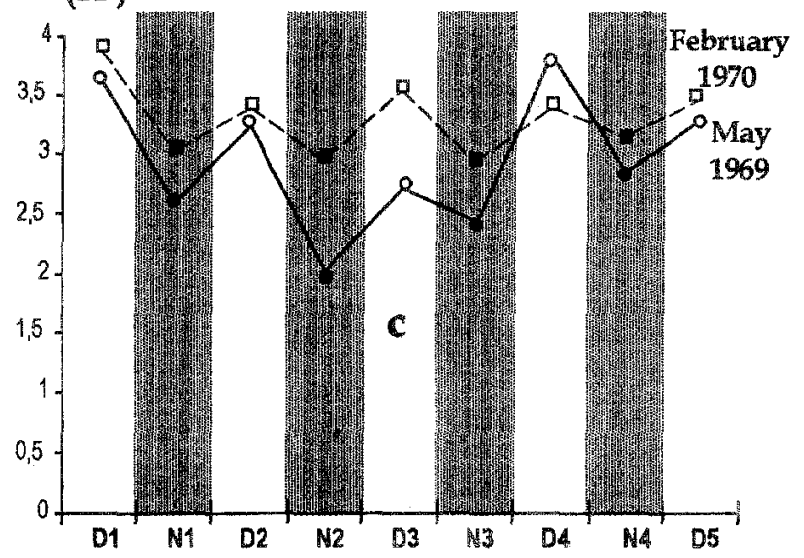

(n)

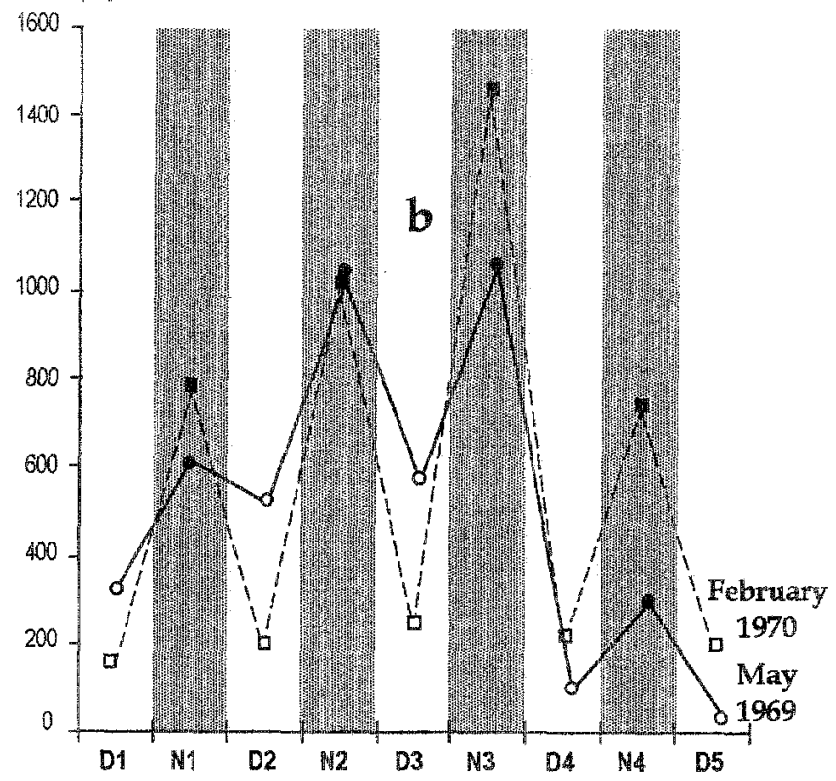

$\left(\mathrm{H}^{\prime} / \mathrm{H}\right)$

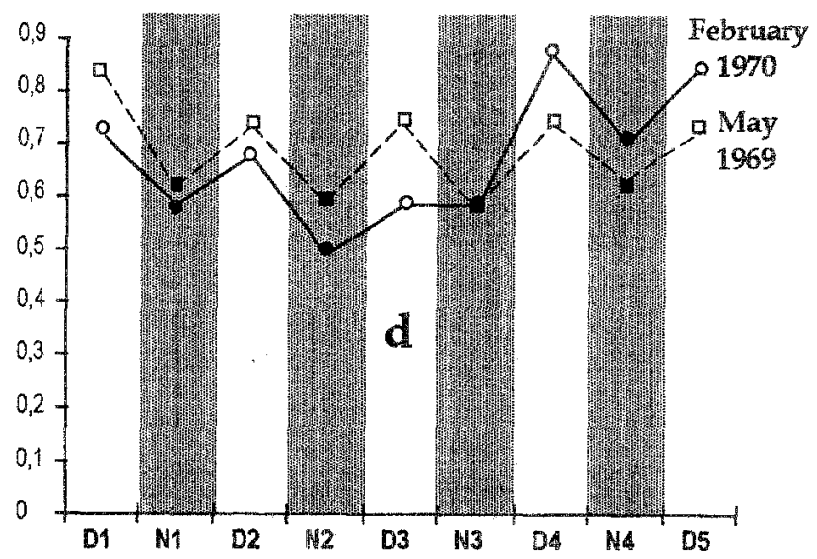

Figure 8. Variations of structural parameters (mean values per successive days and nights) of the community associated with the Penaeit. notialis grounds. (a) species number, s; (b) number of individuals, $\mathbf{n}$; (c) Shannon's diversity, H'; (d) evenness, H'H. Solid lines: May 1969 cruise; dashed lines: February 1970 cruise.

year, mostly during the warm season. These tropical organisms with a short life span have specific reproduction periods [2] and their cohorts, after recruitment to the benthic communities, decreased rapidly in abundance in the following months. So, at each period of the annual hydroclimatic cycle (and the year 1969 is an example that agrees with the pattern described by Morlière [31]), the communities are characterized by a particular species composition and faunal structure. Such seasonal phenomena in the large size epifauna (caught with fish trawls) and in the small epifauna and endofauna (collected with a grab) of the Côte-d'Ivoire continental shelf have been previously shown by Le Loeuff and Intès $[21,22]$. 


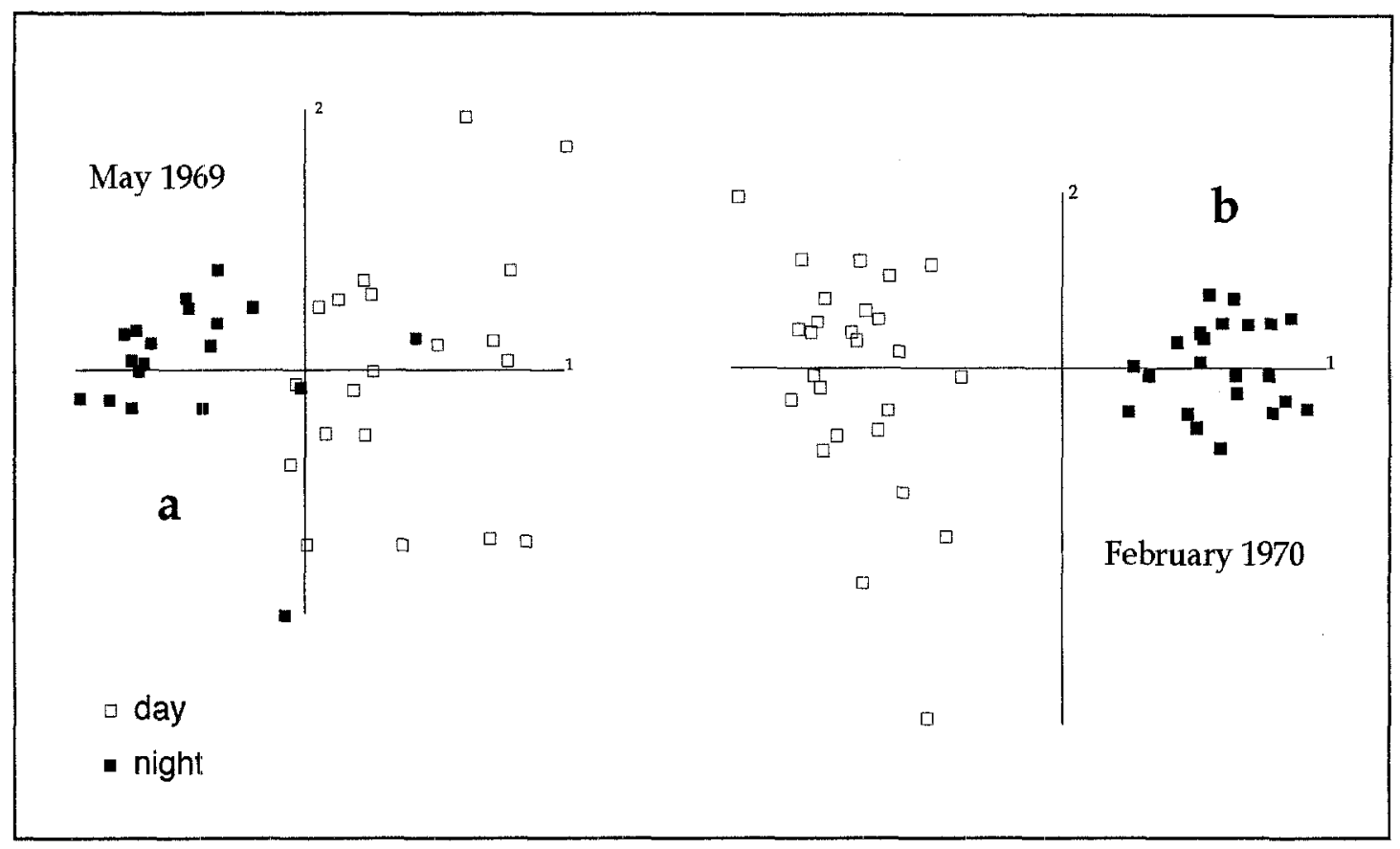

Figure 9. Representation of samples collected during the May 1969 (a), and February 1970 (b) cruises. Results from Correspondence Analysis $(\mathrm{COA})$ on species/data matrix (May, matrix $56 \times 39 ; \%$ total variance, axis $1: 18.4 \%$, axis $2: 8.8 \%$. February, matrix $70 \times 48 ; \%$ total variance, axis $1: 21.7 \%$, axis $2: 6.6 \%$ ).

The main seasonal changes in the coastal marine waters ecosystems of the Côte-d'Ivoire are due to the periodical upwelling of cold waters along the coast during the boreal summer. The influence of the succession of rainy/ dry seasons (variation of the salinity of the superficial waters) becomes of minor importance. Generally, in tropical oceanic areas without upwelling, differences in the faunal composition and structure of the trawlable benthic communities are observed between the dry and rainy seasons as in the Gulf of Mexico [18, 25]. In a subtropical region (Moreton Bay, Queensland, Australia) where the waters appear to be getting cooler in austral winter, Jones [19] observed at that time a drastic impoverishment of the large mobile epibenthos (mostly Portunidae, Squillidae, Scyllaridae, Penaeidae). In Côte-d'Ivoire, during the upwelling season the fauna is also at a lower level (number of species and abundance) [23].

\subsection{The diel cycle}

Some species had the same behaviour in both cruises. Like Paguristes mauritanicus, other species maintain diurnal activity: the pagurid Pagurus alatus (pagurs have an opportunistic feeding strategy [34]); the brachyuran
Calappa pelii (species belonging to the genus Calappa are known to feed during the day upon molluscs and pagurids [40]); the predator asterids, Astropecten irregularis and Luidia heterozona that keep buried during the night (in asterids, the diel cycle varies with the species $[1,28,29]$ ); the cnidarian Metalcyonium violaceum that probably retracts its polyps and contracts its body by night [36]. In the same way as the predator brachyuran Macropipus rugosus, the scyllarid Scyllarus posteli, the peneid Solenocera africana (the behaviour of the close species, Solenocera membranacea, a nocturnal predator, is well described by Heegard, [14]), the brachyuran Sternodromia spinirostris keep a nocturnal activity during the February cruise. This latter behaviour is the most common anong crustacean species $[19,25]$ and may serve to minimise predation by demersal fishes during high-risk (daily) pcriods.

However, from February to May, some variations occurred for instance in the diel cycle of the pagurids Diogenes ovatus and Pagurus cuanensis, the scyllarid Scyllarus caparti, the carid shrimp Pontocaris cataphra$c t a$, the gastropods Xenophora senegalensis and Cymbium patulum (a predator of bivalves [27]), while the burrowing stomatopods Squilla cadenati, Squilla mantis 


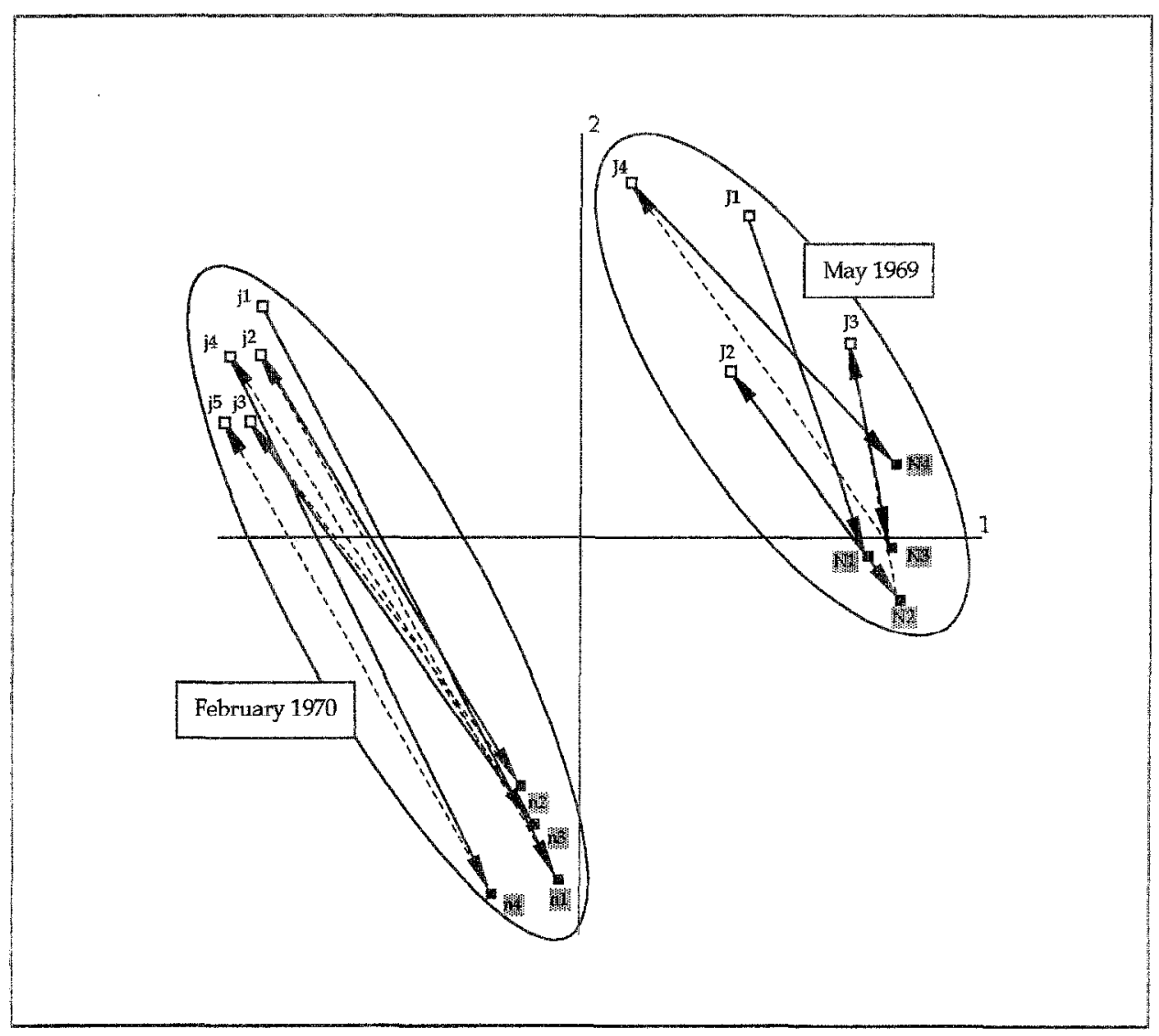

Figure 10. Direct comparison of May and February cruise data. Results from a Correspondence Analysis (COA) on the mean distribution of abundance of species during the course of successive days and nights (matrix $79 \times 17$; \% total variance, axis 1: $37.0 \%$, axis $2: 22.9 \%$ ).

[13], and the brachyurans Medorippe lanata and Machaerus oxyacantha exhibited completely changed nyctimeral rhythms.

From these results it can be concluded that species such as the two Squilla are under the influence of environmental factors, most likely the intensity and wavelength of the light that reaches the sca bottom. The biorhythm of benthic organisms such as Paguristes and Macropipus may be regulated by internal processes [40] as these species need only a very low threshold of light to maintain their diel cycle. These two hypotheses are also put forward to explain the diel periodicity of deep-water crustaceans, Nephropidae and Caridae, on the northwest Australian continental slope, where the Pacific tropical waters are exceptionally clear and transmissive; at $400-500 \mathrm{~m}$, adequate light may be available to induce the observed day-night pattern activity [39]. The diel patterns of some of these deep-water Australian Nephropidae and of the Euro- pean species Nephrops norvegicus $[6,30,32]$ are thought to be very similar.

In May 1969, something happened to prevent or strongly limit light penetration to the bottom. The consequence of the increased rainfall in April-May was an increased flow from the Ébrié lagoon fed by coastal rivers: the water level of the lagoon began to rise from May and the salinity of the lagoon waters at the zone of its confluence with the sea decreased sharply $[10,38]$. In 1975, when the quantity and the pattern of rainfall was quite similar to those of 1969, Dufour [9] observed in May the incidence of a very high phytoplankton biomass in the estuarine part of the lagoon. Taking into account these observations, it can be postulated that turbid water lenses loaded with inorganic and organic particulate material flowing out of the Ébrié lagoon could have been transported to and over the studied area by the eastward-flowing Guinea current, stronger at this time of the year [8]. The consequence of this would be, if not a total absence, at least a 


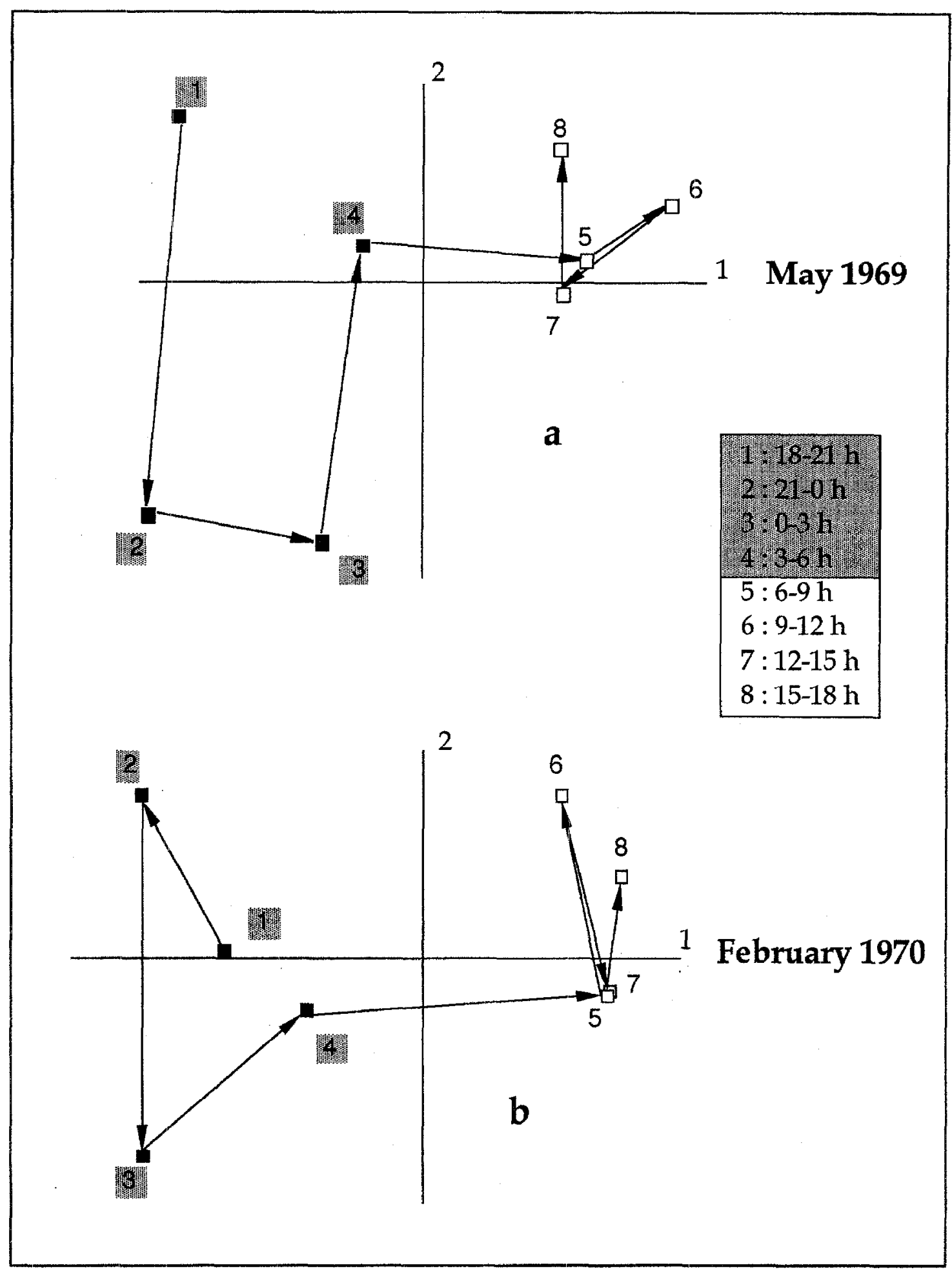

Figure 11. Average diel cycles of the community during the May (a) and February (b) cruises. Results of a Correspondence Analysis (COA) on the mean distribution abundance of the species in successive 3 hour periods (May, matrix $56 \times 8$; \% total variance, axis $1: 47.0 \%$, axis $2: 16.2 \%$. February, matrix $70 \times 8$, \% total variance, axis $1: 61.4 \%$, axis $2: 13.9 \%$ ). 
sharp reduction of light reaching the bottom, inhibiting the nyctimeral rhythms in several species. This change apparently occurred from the second day of the May cruise, but, at the beginning of the fourth day, the fauna recovered a circadian rhythm closer to normal. It is also interesting to note that the changes in the abundance and species number of the benthic fauna in the hauls of May suggest, though difficult to substantiate, an impoverishment of the bottom following repeated trawls at the same site (figure $8 a$ and $b$ ), whereas nothing of this sort was observed during the course of the February 1970 cruise where a greater number of hauls were made. Nevertheless such a phenomenon has been observed on a prawn fishing ground of Australia [12].

\section{CONCLUSION}

In Côte-d'Ivoire, a tropical oceanic area with strong annual variations of the hydroclimate (upwelling), notabie seasonal changes can be obscrved in the faunistic composition and structure of the benthic communities on the continental shelf. The warm season fauna is richer (in abundance and in number of species) than the cold season fauna; each of them is characterized by particnlar species. In fact, it is the whole ecosystem of the Ivorian oceanic area that changes with the hydroclimatic seasonal cycle $[8,31]$; nutrient salts [15], primary production [35], zooplankton [3], benthic fauna [21, 22, 23], demersal fishes [5]. Seasonal variations are also observed in the Penaeus notialis population [11,24]: catches are lower in the middle of the warm season (from January to March) and remained at a higher level during other months; the bathymetric distribution of this peneid species also changes during the cold season (July to September) when the higher catch is obtained on the $35 \mathrm{~m}$ depth bottoms, instead of $45 \mathrm{~m}$.

Diel cycles have also been studied in zooplankton [4] and demersal fishes [5] from Côte-d'Ivoire. The originality of this study is to show that those rhythms can be perturbed by climatic events. In the same way, Penaeus notialis was shown to be a rather nocturnal shrimp, as seen in May 1970 when the catch was three times higher in the night hauls than in the day hauls; but, in February 1969, the night catch was four times lower than the day catch, the better yields being observed at dawn and sunset [11].

A monitoring program of the benthic ecosystem is now starting off Grand-Bassam where this study was carried out. Diurnal and seasonal variations should be taken into account before identifying long-term changes possibly due to climatic changes or to bottom trawling.

\section{REFERENCES}

[1] Beddingfield S.D., Mclintock J.B., Marion K., Hopkins T.S., Feeding biology of the asteroid Astropecten articulatus, Rep Ann. Meet. Am. Soc. Zool. 31 (1991) 28 (summary only).

[2] Binet D., Grands traits de l'écologie des principaux taxons du zooplancton ivoirien, Cah. Orstom sér. Océanogr. 15 (1977) 89-109.

[3] Binet D., Le zooplancton du plateau continental ivoirien, Essai de synthèse écologique, Oceanol. Acta 2 (1979) 397-410.

[4] Binet D., Zooplancton néritique de Côte-d'Ivoire, in: Le Loeuff P., Marchal É., Amon Kothias J.B. (Eds.), Environnement et ressources aquatiques de Côte-d'Ivoire, tome I- Le milieu marin, Orstom, Paris, 1993, pp. 167-193.

[5] Caverivière A., Les peuplements ichtyologiques démersaux, écologie et biologie, in: Le Loeuff P., Marchal É., Amon Kothias J.B. (Eds.), Environnement et ressources aquatiques de Côte-d'Ivoire, tome I- Le milieu marin. Orstom, Paris, 1993, pp. 271-320.

[6] Chapman C.J., Howard F.G., Field observations on the emergence rhythm of the Norway lobster, Nephrops norvegicus, using different methods, Mar. Biol. 51 (1979) 157-165.
[7] Cieh/Asecna/Orstom, République de Côte-d'Ivoire, Précipitations journalières de 1966 à 1980, 1989, $609 \mathrm{p}$.

[8] Colin C., Gallardo Y., Chuchla R., Cissoko S., Environnements climatique et océanographique sur le plateau continental de Côte-d'Tvoire, in: Le Loeuff P., Marchal É., Amon Kothias J.B. (Eds.), Environnement et ressources aquatiques de Côte-d'Ivoire, tome I- Le milieu marin, Orstom, Paris, 1993, pp. 76-110.

[9] Dufour P., La biomasse végétale des lagunes côtières, Exernple de la lagune Ébrié (Côte-d'Tvoire), Rev. Hydrobiol. Trop. 17 (1984) 207-233.

[10] Durand J.R., Guiral D., Hydroclimat et hydrochimie, in: Durand J.R., Dufour P., Guiral D., Zabi S.G.F. (Eds.), Environnement el ressources aquatiques de Cote-d'Ivoire, tome II- Les milieux lagunaires, Orstom, Paris, 1994, pp. 59-90.

[11] Garcia S., Biologie et dynamique des populations de crevettes roses (Penaeus duorarum notialis Perèz Farfante, 1967) en Côte-d'Ivoire, Trav. Doc. Orstom 79, 1977, 1-271.

[12] Gibbs P.J., Collins A.J., Collett L.C., Effect of otter prawn trawling on the macrobenthos of a sandy substratum in a New 
South Wales estuary, Aust. J. Mar. Freshwater Res. 31 (1980) 509-516.

[13] Givanardi O., Piccinetti M.G., Summary of biological parameters of Squilla mantis L. in the Adriatic sea, FAO Fish. Rep. 290 (1984) $131-134$.

[14] Heegard P., On behaviour, sex-ratio and growth of Solenocera membranacea (Risso) (Decapoda, Peneidea), Crustaceana 13 (1967) 227-237.

[15] Herbland A., Le Loeuff P., Les sels nutritifs au large de la Côte-d'Ivoire, in: Le Loeuff P., Marchal É., Amon Kothias J.B. (Eds.), Environnement et ressources aquatiques de Côted'Ivoire, tome I- Le milieu marin, Orstom, Paris, 1993, pp. $123-148$.

[16] Hildebrand H.H., A study of the fauna of the brown shrimp (Penaeis. azterus Tves) grounds in the western Gulf of Mexico, Publ. Inst. Mar. Sci. Univ. Texas 3, 1954, 233-366.

[17] Hildebrand H.H., A study of the fauna of the pink shrimp (Penaeus duorarum Burkenroad) grounds in the Gulf of Campeche, Publ. Inst. Mar. Sci. Univ. Texas 4 (1955) 171-232.

[18] Hoese H.D., Copeland B.J., Moseley F.N., Lane E.D., Fauna of the Aransas Pass Inlet, Texas: III. Diel and seasonal variations in trawlable organisms of the adjacent area, Texas J. Sci. 20 (1968) 33-60.

[19] Jones A.R., Spatial and temporal variations in a community of nektobenthic invertebrates from Moreton Bay, Queensland, Est. Coast. Shelf Sici. 23 (1986) 131-146.

[20] Le Loeuff P., La faune benthique des fonds chalutables du plateau continental de la Guinée, Premiers résultats en référence à la faune de la Côte-d'Ivoire, Rev. Hydrobiol. Trop. 26 (1993) 229-252.

[21] Le Loeuff P., Intès A., La faune benthique du plateau continental de Côte-d'Ivoire, Récoltes au chalut: abondance, dominance, répartition, variations saisonnières, Doc. Scient. Prov. Centre Rech. Océanogr. Abidjan 25 (1968) 1-110.

[22] Le Loeuff P., Intès A., La faune benthique du plateau continental de Côte-d'Ivoire, in: Le Loeuff P., Marchal É., Amon Kothias J.B. (Eds.), Environnement et ressources aquatiques de Côte-d'Ivoire, tome I- Le milieu marin, Orstom, Paris, 1993, pp. 195-236.

[23] Le Locuff P., Intès A., La faune benthique associée aux fonds à crevettes pénéides (Penceus notialis) de la Côte-d'Ivoire, Doc. Scient. Tech. Centre Orstom Brest 82 (1998) 1-160.

[24] Lhomme F., Vendeville P., La crevette rose Penaeus notialis (Pérez Farfante, 1967) en Côte-d'Ivoire, in: Le Loeuff P., Marchal É., Amon Kothias J.B. (Eds.), Environnement et ressources aquatiques de Côte-d'Ivoire, tome I- Le milieu marin, Orstom, Paris, 1993, pp. 489-520.
[25] Livingston R.J., Diumal and seasonal fluctuations of organisms in a North Florida estuary, Fst. Coast. Mar. Sci. 4 (1976) 373-400.

[26] Long B.G., Poiner I.R., Wassenberg T.J., Distribution, biomass and community structure of megabenthos of the Gulf of Carpentaria, Australia, Mar. Ecol. Prog. Ser. 129 (1995) 127-139.

[27] Marche-Marchad I, Recherches sur la biologie des Volutidae du genre ouest-africain Cymbium (Gastropoda, Prosobranchia), thèse doc. État, univ. Paris VI, 1975, 276 p.

[28] Massé H., Ethologie alimentaire d'Astropecten aranciacus L., Proc. 9th Europ. Symp. mar. Biol., 1975, 343-355.

[29] McLintock J.B., The daily activity pattern of Luidia clathrata (Say) (Echinodermata: Asteroidea) in Tampa Bay, Rep. 44th Ann. Meet. Acad. Tampa 43, 1980, p. 16 (summary only).

[30] Moller T.H., Naylor E., Environmental influence on locomotor activity in Nephrops norvegicus (Crustacea: Decapoda), J. Mar. Biol. Assoc. U.K. 60 (1980) 103-113.

[31] Morlière A., Les saisons marines devant Abidjan, Doc. Scient. Centre Rech. Océanogr. Abidjan 2 (1970) 1-30.

[32] Oakley S.G., Diurnal and seasonal changes in the timing and peak catches of Nephrops norvegicus reflecting changes in behaviour, in: Naylor E., Hartnoll R.G. (Eds.), Cyclic behaviour in marine plants and animals, Pergamon Press, Oxford, 1979, pp. 367-373.

[33] Privé M., Corre D., Les stations côtières fixes de la côte ouest. africaine, Valeurs et graphiques annuels de température et salinité, II- Côtières de Côte-d'Ivoire, Orstom, Brest, 1979, 172 p.

[34] Scully E.P., The behavioral ecology of competition and resource utilization among hermit crabs, in: Rebach S., Dunham D.W. (Eds.), Studies in adaptation, the behavior of higher crustacea, John Wiley \& sons, 1983, pp. 23-50.

[35] Sevrin-Reyssac J., Phytoplancton et production primaire dans les eaux marines ivoiriennes, in: Le Loeuff P., Marchal É., Amon Kothias J.B. (Eds.), Environnement et ressources aquatiques de Côte-d'Ivoire, tome I- Le milieu marin, Orstom, Paris, 1993, pp. 151-166.

[36] Tixier-Durivault A., Sous-classe des octocoralliaires, in: Grassé P.P. (Ed.), Traité de zoologie, Anatomie, systématique, biologie, Masson, Paris, 1987, pp. 3-185.

[37] Troadec J.P., Garcia S., Petit P., L'exploitation des crevettes en Côte-d'Ivoire, De solides raisons d'espérer, La Pêche maritime 1095 (1969) 434-436.

[38] Varlet F., Le régime de la lagune Ébrié (Côte-d'Ivoire), Traits physiques essentiels, Trav. Doc. Orstom 83 (1978) 1-164.

[39] Ward T.J., Davies T.L.O., Diel periodicity of Metanephrops australiensis and other deep-water crustaceans of Northwcst Australia, Fish. Res. 5 (1987) 91-97.

[40] Warner G.F., The biology of crabs, Paul Elek, London, 1977 , $202 \mathrm{p}$. 
Annex In Species collected during the cruises off Grand-Bassam (Côte-d'lvoire) from January, 1969 to January, 1970. Indication is given l: their occurrence and total abundance in the hauls and of their observed vertical distribution.

\begin{tabular}{|c|c|c|c|}
\hline Species & Decurrence & Abundance & Vertical distribution (m) \\
\hline \multicolumn{4}{|l|}{ SPONGES } \\
\hline Ficulina ficus (Linnaeus, 1767) & 2 & 3 & 40 \\
\hline \multicolumn{4}{|l|}{ CNIDARIANS } \\
\hline Epizoanthus senegambiensis (Carter, 1882) & 2 & 2 & $25-50$ \\
\hline Balanophyllia floridana (Pourtalès, 1871) & 7 & 11 & $45-50$ \\
\hline Veretillum cynomorium Pallas, 1766 & 1 & 1 & 40 \\
\hline Cavernularia mirifica Tixier-Durivault, 1963 & 4 & 5 & 25 \\
\hline Virgularia tuberculata Marshall, 1883 & 1 & 1 & 30 \\
\hline Alcyonium monodi Tixier-Durivault, 1955 & 29 & 71 & $25-40$ \\
\hline Alcyonium altum Tixier-Durivault, 1955 & 29 & $117 !$ & $30-40$ \\
\hline Alcyonium laeve Tixier-Durivault, 1955 & 3 & 19 & $30-40$ \\
\hline Metalcyonium violaceum (Tixier-Durivault 1955) & 48 & 410 & $30-55$ \\
\hline Bellonella madseni Tixier-Durivault, 1961 & 9 & 123 & $30-50$ \\
\hline \multicolumn{4}{|l|}{ POLYCHAETES } \\
\hline Aphrodita alta Kinberg, 1855 & 8 & 11 & $25-60$ \\
\hline Hermodice carunculata (Pallas, 1766) & 13 & 31 & $35-60$ \\
\hline Diopatra neapolitana Delle Chiaje, 1841 & 10 & 33 & $35-60$ \\
\hline \multicolumn{4}{|l|}{ CRUSTACEANS } \\
\hline Squilla aculeata calmani Holthuis, 1959 & 11 & 30 & $25-35$ \\
\hline Squilla cadenati Manning, 1970 & 18 & 80 & $40-55$ \\
\hline Squilla mantis (Linnaeus, 1758) & 26 & 180 & $25-50$ \\
\hline Solenocera africana Stebbing, 1917 & 6 & 9 & $40-45$ \\
\hline Metapenaeopsis miersi (Holthuis, 1952) & 18 & 35 & $25-60$ \\
\hline Sicyonia galeata Holthuis, 1952 & 67 & 1689 & $25-55$ \\
\hline Parapandalus narval (Fabricius, 1787) & 9 & 131 & $45-60$ \\
\hline Alpheus intrinsecus Bate, 1888 & 2 & 2 & $30-35$ \\
\hline Hippolysmata hastatoides (Balss, 1914) & 1 & 12 & 25 \\
\hline Nematopalaemon hastatus (Aurivillius, 1898) & 4 & 3632 & 25 \\
\hline Pontocaris cataphracta (Olivi, 1792) & 30 & 65 & $25-50$ \\
\hline Panulirus rissoni Desmaret, 1825 & 2 & 2 & 25 \\
\hline Scyllanus caparti Holthuis, 1952 & 70 & 1061 & $25-55$ \\
\hline Scyllarus posteli Forest, 1963 & 90 & 2672 & $25-60$ \\
\hline Scyllarides herklotsi (Herklots, 1851) & 1 & 1 & 35 \\
\hline Stenopus spinosus Risso, 1826 & 1 & 1 & 55 \\
\hline Paguristes difficilis Forest, 1952 & 1 & 3 & 30 \\
\hline Paguristes mauritanicus Bouvier, 1906 & 43 & 304 & $25-60$ \\
\hline Paguristes virilis Forest, 1952 & 1 & 2 & 25 \\
\hline Diogenes pugilator Roux, 1829 & 8 & 13 & $25-45$ \\
\hline Diogenes ovatus Miers, 1881 & 26 & 71 & $25-50$ \\
\hline Petrochirus pustulatus (H. Milne Edwards, 1848) & 6 & 6 & $25-50$ \\
\hline Dardanus arrosor (Herbst, 1796) & 2 & 2 & $45-50$ \\
\hline Dardanus pectinatus (Ortmann, 1892) & 31 & 46 & $25-45$ \\
\hline Pagurus mbizi Forest, 1955 & 15 & 25 & $30-60$ \\
\hline Pagurus alatus Fabricius, 1775 & 47 & 93 & $30-60$ \\
\hline Pagurus cuanensis Bell, 1846 & 16 & 22 & $30-55$ \\
\hline Pagurus triangularis (Chevreux and Bouvier, 1892) & 22 & 43 & $25-50$ \\
\hline Paguridium minimum (Chevreux and Bouvier, 1892) & 5 & 7 & $40-60$ \\
\hline Spiropagunus elegans Miers, 1881 & 4 & 4 & $25-30$ \\
\hline Raninoides bouvieri Capart, 1951 & 1 & 1 & 45 \\
\hline Dromia monodi (Forest and Guinot, 1966) & 1 & 1 & 50 \\
\hline Sternodromia spinirostris (Miers, 1881) & 9 & 23 & $40-60$ \\
\hline
\end{tabular}


Annex I. (continued).

\begin{tabular}{|c|c|c|c|}
\hline Species & Occurrence & Abundance & Vertical distribution (m) \\
\hline Homola harhata (Fabricius, 1793) & 8 & 10 & $40-60$ \\
\hline Ethusa vossi Manning and Holthuis, 1981 & 4 & 5 & $35-50$ \\
\hline Phyllodorippe armata (Miers, 1881) & 49 & 2413 & $25-40$ \\
\hline Medorippe lanata (Linnaeus, 1767) & 69 & 1226 & $25-60$ \\
\hline Matuta michaelseni Balss, 1921 & 5 & 6 & $25-35$ \\
\hline Calappa rubroguttata Herklots, 1851 & 24 & 322 & $25-45$ \\
\hline Calappa pelii Herklots, $185 \mathrm{I}$ & 45 & 362 & $30-60$ \\
\hline llia spinosa Miers, 1881 & 14 & 22 & $30-50$ \\
\hline Pseudonyra mbizi Capart, 1951 & 30 & 121 & $45-60$ \\
\hline Liocarcinus corrugatus (Pennant, 1777) & 6 & 12 & $25-45$ \\
\hline Macropipus rugosus (Doflein, 1904) & 39 & 846 & $30-55$ \\
\hline Cronius ruber (Lamarck, 1818) & 14 & 21 & $25-35$ \\
\hline Portunus inaequalis (Miers, 1881) & 48 & 802 & $25-50$ \\
\hline Portunus validus Herklots, 185] & 17 & 63 & $25-35$ \\
\hline Callinectes pallidus (de Rochebrune, 1883) & 23 & 412 & $25-40$ \\
\hline Callinectes amnicola (de Rochebrune, 1883) & 7 & 18 & $25-30$ \\
\hline Machaerus oxyacantha (Monod, 1956) & 25 & 105 & $25-50$ \\
\hline Apiomithrax bocagei (Osorio, 1887$)$ & 15 & 25 & $25-40$ \\
\hline Inachus angolensis Capart, 1951 & 11 & 19 & $45-60$ \\
\hline Inachus leptochirus Leach, 1817 & 3 & 3 & $40-45$ \\
\hline Capartiella longipes (Capart, 1951) & 3 & 3 & $45-55$ \\
\hline Achaeus monodi (Capart, 1951) & 1 & 1 & 30 \\
\hline Macropodia gilsoni (Capart, 1951) & 4 & 5 & $40-60$ \\
\hline Macropodia spinusola (Miers. 1881) & 15 & 17 & $30-45$ \\
\hline Stenorhynchus lanceolatus (Brullé, 1837) & 24 & 45 & $30-50$ \\
\hline Parthenope notialis Manning and Holthuis, 1981 & 37 & 127 & $40-60$ \\
\hline \multicolumn{4}{|l|}{ MOLLUSCS } \\
\hline Calliostoma hernandezi Salazar and Gubbioli, 1993 & 11 & 23 & $30-60$ \\
\hline Turritella ungulina Linnaeus, 1758 & 2 & 2 & $35-40$ \\
\hline Turritella ligar Deshayes, 1843 & 2 & 2 & $25-30$ \\
\hline Turritella annulata Kiener, 1853 & 6 & 7 & $35-55$ \\
\hline Architectonica nobilis (Röding, 1798) & 2 & 2 & $35-40$ \\
\hline Xenophora senegalensis Fischer, 1873 & 18 & 57 & $30-55$ \\
\hline Natica fanel Recluz, 1843 & 3 & 3 & $25-50$ \\
\hline Natica canariensis Ohdner, 1931 & 1 & 1 & 55 \\
\hline Sigaretus concavus Lamarck, 1822 & 13 & 38 & $25-40$ \\
\hline Cypraea petitiana Crosse, 1873 & 2 & 2 & $30 \cdot 35$ \\
\hline Phalium saburon Bruguière, 1792 & 10 & 11 & $30-60$ \\
\hline Distorsio ridens (Reeve, 1844) & 10 & 26 & $30-50$ \\
\hline Murex comutus Linnaeus, 1758 & 6 & 6 & $30-55$ \\
\hline Murex rosarium Chemnitz, 1788 & 14 & 21 & $30-50$ \\
\hline Murex varius Sowerby, 1834 & 22 & 40 & $25-50$ \\
\hline Trophon fusulus (Brocchi, 1814) & 5 & 5 & $45-60$ \\
\hline Coralliophila meyendorffi Calcara, 1862 & 1 & 1 & 40 \\
\hline Phos grateloupianus Petit de la Saussaye, 1853 & 3 & 3 & $40-50$ \\
\hline Metula cumingi Adams, 1858 & 4 & 4 & $25-60$ \\
\hline Nassarius tritoniformis (Kiener, 1835) & 3 & 5 & 25 \\
\hline Nassarius turbineus (Gould, 1845) & 4 & 5 & $50-60$ \\
\hline Lathyrus filosus Schubert and Wagner, 1829 & 5 & 5 & $30-45$ \\
\hline Fusus caparti Adam and Knudsen, 1955 & 3 & 3 & $30-35$ \\
\hline Tudicla afra Gmelin, 1790 & 11 & 29 & $30-55$ \\
\hline Cymbium glans (Gmelin, 1791) & 2 & 2 & $25-30$ \\
\hline
\end{tabular}


Annex I. (continued).

\begin{tabular}{|c|c|c|c|}
\hline Species & Occurrence & Abundance & Vertical distribution (m) \\
\hline Cymbium patulum (Broderip, 1830) & 27 & 46 & $35-60$ \\
\hline Cymbium souliei Marche-Marchad, 1974 & 3 & 5 & 25 \\
\hline Cancellaria cancellata Linnaeus, 1767 & 6 & 6 & $30-60$ \\
\hline Marginella cincta Kiener, 1834 & 3 & 3 & $30-40$ \\
\hline Drillia rosacea (Reeve, 1845 ) & 4 & 4 & $30-50$ \\
\hline Clavatula muricata (Lamarck, 1822) & 2. & 3 & $30-40$ \\
\hline Clavatula diadema Kiener, 1841 & 11 & 20 & $40-60$ \\
\hline Clavatula lelieuri (Recluz, 1851) & 10 & 11 & $25-55$ \\
\hline Clavatula aculeifomis (Lamarck, 1822) & 1 & 1 & 25 \\
\hline Turris undatiruga (Bivona, 1832) & 2 & 2 & $50-60$ \\
\hline Turris consociata (Smith, 1877) & 1 & 1 & 45 \\
\hline Genota mitraeformis (Wood, 1828) & 4 & 6 & $40-50$ \\
\hline Genota nicklesi Knudsen, 1952 & 1 & 2 & 25 \\
\hline Terebra corrugata Lamarck, 1822 & 9 & 9 & $30-55$ \\
\hline Hydatina physis Linnaeus, 1758 & 1 & 2 & 30 \\
\hline Philine aperta Linnaeus, 1767 & 26 & 215 & $25-50$ \\
\hline Pleurobranchaea gela Marcus and Marcus, 1966 & 27 & 708 & $25-50$ \\
\hline Marionia pusa Marcus and Marcus, 1968 & $?$ & 2 & $35-40$ \\
\hline Fimbria fimbria (Linnaeus, 1767) & 16 & 129 & $25-55$ \\
\hline Armina adami White, 1955 & 1 & 4 & 40 \\
\hline Amina bayeri Marcus and Marcus, 1966 & 7 & 8 & $25-35$ \\
\hline Nucula nitidosa Winckworth, 1930 & 5 & 9 & $45-60$ \\
\hline Nucula sulcata Bronn, 1831 & 1 & 4 & 60 \\
\hline Lissochlamys exoticus (Dillwyn, 1817) & 9 & 320 & $25-30$ \\
\hline Aequipecten minutus (Nicklès, 1955) & 1 & 1 & 45 \\
\hline Crassatella paeteli Maltzan, 1885 & 1 & 1 & 50 \\
\hline Crassatella triquetra Reeve, 1842 & 4 & 6 & $40-55$ \\
\hline Cardita umbonata (Sowerby, 1904) & 1 & 1 & 60 \\
\hline Pitar elata (Sowerby, 1908) & 1 & 2 & 60 \\
\hline \multicolumn{4}{|l|}{ ECHINODERMS } \\
\hline Antedon dubenii Bölsche, 1866 & 44 & 290 & $25-55$ \\
\hline Astropecten irregularis Pennant, 1777 & 24 & 62 & $30-50$ \\
\hline Astropecten michaelseni Koehler, 1914 & 14 & 40 & $25-40$ \\
\hline Astropecten jarli Madsen, 1950 & 1 & 1 & 50 \\
\hline Astropecten hupferi Kochler, 1914 & 1 & 1 & 50 \\
\hline Luidia atlantidea Madsen, 1950 & 34 & 139 & $25-50$ \\
\hline Luidia heterozona Fisher, 1940 & 46 & 105 & $25-60$ \\
\hline Luidia numidica Koehler, 1911 & 21 & 30 & $25-50$ \\
\hline Centrostephanus longispinus (Philippi, 1845) & 18 & 25 & $40-60$ \\
\hline Genocidaris maculata A. Agassiz, 1869 & 3 & 17 & $35-40$ \\
\hline Schizaster edwardsi Cotteau, 1889 & 13 & 611 & $25-45$ \\
\hline Hemioedema goreensis Cherbonnicr, 1949 & 5 & 5 & $25-35$ \\
\hline \multicolumn{4}{|l|}{ BRYOZOANS } \\
\hline Cupuladrio canariensis (Busk, 1859) & 21 & 118 & $30-60$ \\
\hline Hippoporidra senegambiensis (Carter, 1882) & 10 & 39 & $40-50$ \\
\hline
\end{tabular}


Annex II. Species collected during the May 1969 cruise on the $45 \mathrm{~m}$ depth bottoms off Grand-Bassam (Côte-d'Ivoire) with indication of their occurrence and total abundance in the day (D) and night (N) hauls.

\begin{tabular}{|c|c|c|c|c|}
\hline Species & Occurrence D & Occurrence $\mathrm{N}$ & Abundance D & Abundance $\mathbf{N}$ \\
\hline \multicolumn{5}{|l|}{ SPONGES } \\
\hline Ficulina ficus (Linnaeus, 1767) & 4 & 0 & 4 & 0 \\
\hline \multicolumn{5}{|l|}{ CNIDARIANS } \\
\hline Balanophyllia floridana (Pourtalès, 1871) & 1 & 0 & 1 & 0 \\
\hline Alcyonium ullum Tixier-Durivault, 1955 & 1 & 0 & 1 & 0 \\
\hline Metalcyonium violaceum (Tixier-Durivault, 1955) & 19 & 15 & 131 & 63 \\
\hline Bellonella madseni Tixier-Durivault, 1961 & 3 & 3 & 3 & 6 \\
\hline \multicolumn{5}{|l|}{ POLYCHAETES } \\
\hline Diopatra neapolitana Delle Chiaje, 1841 & 1 & $\mathbf{0}$ & 1 & 0 \\
\hline \multicolumn{5}{|l|}{ CRUSTACEANS } \\
\hline Squilla cadenati Manning, 1970 & 14 & 15 & 83 & 45 \\
\hline Squilla mantis (Linnaeus, 1758) & 14 & 19 & 214 & 162 \\
\hline Solenocera africana Stebbing, 1917 & 2 & 15 & 5 & 140 \\
\hline Metapenaeopsis miersi (Holthuis, 1952) & 1 & 2 & 1 & 2 \\
\hline Sicyonia galeata Holthuis, 1952 & 20 & 19 & 573 & 2278 \\
\hline Parapandalus narval (Fabricius, 1787) & 0 & 1 & 0 & 1 \\
\hline Alpheus intrinsecus Bate, 1888 & 0 & 1 & 0 & 1 \\
\hline Pontocaris cataphracta (Olivi, 1792) & 10 & 11 & 27 & 59 \\
\hline Scyllarus caparti Holthuis, 1952 & 20 & 19 & 1394 & 1649 \\
\hline Scyllarus posteli Forest, 1963 & 20 & 19 & 2710 & 5304 \\
\hline Paguristes mauritanicus Bouvier, 1906 & 20 & 8 & 91 & 35 \\
\hline Diogenes pugilator Roux, 1829 & 1 & 0 & 1 & $\mathbf{0}$ \\
\hline Diogenes ovatus Miers, 1881 & 18 & 7 & 102 & 21 \\
\hline Petrochirus pustulatus (H. Milne Edwards, 1848) & 2 & 2 & 2 & 2 \\
\hline Dardanus pectinatus (Ortmann, 1892) & 13 & 4 & 19 & 4 \\
\hline Pagurus mbizi Forest, 1955 & 5 & 2 & 9 & 2 \\
\hline Pagurus alatus Fabricius, 1775 & 20 & 8 & 51 & 11 \\
\hline Pagurus cuanensis Bell, 1846 & 11 & 2 & 19 & 3 \\
\hline Pagurus triangularis (Chevreux and Bouvier, 1892) & 3 & 0 & 8 & $\mathbf{0}$ \\
\hline Paguridium minimum (Chevreux and Bouvier, 1892) & 0 & 1 & 0 & 1 \\
\hline Sternodromia spinirostris Miers, 1881 & 4 & 13 & 4 & 30 \\
\hline Homola barbata (Fabricius, 1793) & 0 & 2 & 0 & 5 \\
\hline Ethusa vossi Manning and Holthuis, 1981 & 1 & 0 & 1 & 0 \\
\hline Phyllodorippe armata (Miers, 1881) & 2 & 0 & 2 & $\mathbf{0}$ \\
\hline Medorippe lanata (Linnaeus, 1767) & 19 & 19 & 505 & 490 \\
\hline Calappa rubroguttata Herklots, 1851 & 5 & 1 & 5 & 1 \\
\hline Calappa pelii Herklots, 1851 & 13 & 6 & 29 & 8 \\
\hline Ilia spinosa Miers, 1881 & 9 & 3 & 12 & 3 \\
\hline Macropipus rugosus (Doflein, 1904) & 19 & 19 & 803 & 2776 \\
\hline Portunus inaequalis (Miers, 1881) & 17 & 17 & 249 & 603 \\
\hline Leopoldius pisifer (MacLeay, 1838) & 1 & $\mathbf{0}$ & 1 & 0 \\
\hline Machaerus oxyacantha (Monod, 1956) & 15 & 9 & 73 & 23 \\
\hline Macropodia spinusola (Miers, 1881) & 1 & 1 & 1 & 1 \\
\hline Stenorhynchus lanceolatus (Brullé, 1837) & 7 & 10 & 11 & 13 \\
\hline Parthenope notialis Manning and Holthuis, 1981 & 17 & 13 & 57 & 31 \\
\hline \multicolumn{5}{|l|}{ MOLLUSCS } \\
\hline Calliostoma hernandezi Salazar and Gubbioli, 1993 & 7 & 3 & 8 & 3 \\
\hline Turritella annulata Kiener, 1853 & 3 & $\mathbf{0}$ & 3 & $\mathbf{0}$ \\
\hline Architectonica nobilis (Röding, 1798) & 3 & 1 & 4 & 1 \\
\hline Xenophora senegalensis Fischer, 1873 & 13 & 6 & 24 & 8 \\
\hline Natica canariensis Ohdner, 1931 & 0 & 1 & 0 & 1 \\
\hline
\end{tabular}


Annex II. (continued).

\begin{tabular}{|c|c|c|c|c|}
\hline Species & Occurrence D & Occurrence $\mathrm{N}$ & Abundance D & Abundance $\mathrm{N}$ \\
\hline Phatium saburon Bruguière, 1792 & 1 & 3 & 1 & 4 \\
\hline Distorsio ridens (Reeve, 1844) & 5 & 2 & 6 & 2 \\
\hline Tonna galea Linnaeus, 1758 & 0 & 2 & 0 & 2 \\
\hline Murex cornutus Linnaeus, 1758 & 4 & 1 & 6 & 2 \\
\hline Murex rosarium Chemnitz, 1788 & 7 & 4 & 8 & 5 \\
\hline Murex varius Sowerby, 1834 & 3 & 3 & 5 & 2 \\
\hline Trophon fusulus (Brocchi, 1814) & 1 & 0 & 0 & 1 \\
\hline Coralliophila kraemmeri Knudsen, 1956 & 1 & 0 & 1 & 0 \\
\hline Phos grateloupianus Petit de la Saussaye, 1853 & 4 & 2 & 4 & 2 \\
\hline Metula cumingi Adams, 1858 & 2 & 0 & 2 & $\mathbf{0}$ \\
\hline Nassarius turbineus (Gould, 1845) & 3 & 0 & 3 & $\mathbf{0}$ \\
\hline Lathyrus filosus Schubert and Wagner, 1829 & 1 & 0 & 2 & 0 \\
\hline Tudicla afra Gmelin, 1790 & 11 & 2 & 16 & 3 \\
\hline Cymbium patulum (Broderip, 1830) & 8 & 11 & 13 & 31 \\
\hline Cancellaria cancellata Linnaeus, 1767 & 2 & 1 & 2 & 1 \\
\hline Marginella cincta Kiener, 1834 & 1 & 1 & 2 & 1 \\
\hline Clavatula muricata (Lamarck, 1822) & 0 & 1 & 0 & 1 \\
\hline Clavatula diadema Kiener, 1841 & 5 & 2 & 5 & 3 \\
\hline Clavatula lelieuri (Recluz, 1851) & 1 & 1 & 1 & 2 \\
\hline Clavatula aculeiformis (Lamarck, 1822) & 1 & 1 & 1 & 1 \\
\hline Turris undatiruga (Bivona, 1832) & 1 & 0 & 1 & 0 \\
\hline Genota mitraeformis (Wood, 1828) & 2 & 1 & 2 & 1 \\
\hline Terebra corrugata Lamarck, 1822 & 1 & $\mathbf{0}$ & 1 & 0 \\
\hline Philine aperta Linnaeus, 1767 & 8 & 3 & 15 & 5 \\
\hline Pleurobranchaea gela Marcus and Marcus, 1966 & 0 & 3 & 0 & 3 \\
\hline Marionia pusa Marcus and Marcus, 1968 & 1 & 0 & 1 & $\mathbf{0}$ \\
\hline Fimbria fimbria (Linnaeus, 1767) & 4 & 0 & 4 & 0 \\
\hline Crassatella triquetra Reeve, 1842 & 2 & $\mathbf{0}$ & 2 & 0 \\
\hline \multicolumn{5}{|l|}{ ECHINODERMS } \\
\hline Antedon dubenii Bölsche, 1866 & 4 & 5 & 4 & 6 \\
\hline Astropecten irregularis Pennant, 1777 & 14 & 6 & 21 & 7 \\
\hline Astropecten jarli Madsen, 1950 & 3 & 1 & 3 & 2 \\
\hline Luidia atlantidea Madsen, 1950 & 8 & 3 & 12 & 3 \\
\hline Luidia heterozona Fisher, 1940 & 19 & 15 & 154 & 94 \\
\hline Luidia numidica Koehler, 1911 & 1 & 0 & 1 & 0 \\
\hline Centrostephanus longispinus (Philippi, 1845) & 8 & 7 & 13 & 14 \\
\hline \multicolumn{5}{|l|}{ BRYOZOANS } \\
\hline Cupuladria canariensis (Busk, 1859) & 9 & 5 & 31 & 10 \\
\hline Hippoporidra senegambiensis (Carter, 1882) & 15 & 7 & 84 & 23 \\
\hline
\end{tabular}


Annex III. Species collected during the February 1970 cruise on the $45 \mathrm{~m}$ depth bottoms off Grand-Bassam (Côte-d'Ivoire), with indication of their occurrence and total abundance in the day (D) and night (N) hauls.

\begin{tabular}{|c|c|c|c|c|}
\hline Species & Occurrence D & Occurrence $\mathbf{N}$ & Abundance D & Abundance $\mathbf{N}$ \\
\hline \multicolumn{5}{|l|}{ CNIDARIANS } \\
\hline Balanophyllia floridana (Pourtalès, 1871) & 1 & 0 & 3 & 0 \\
\hline Alcyonilum altum Tixier-Durivault, 1955 & 1 & $\mathbf{0}$ & 1 & 0 \\
\hline Metalcyonium violaceum (Tixier-Durivault, 1955) & 26 & 22 & 1156 & 523 \\
\hline Bellonella madseni Tixier Durivault, 1955 & 26 & 22 & 322 & 343 \\
\hline \multicolumn{5}{|l|}{ POLYCHAETES } \\
\hline Aphrodita alta Kinberg. 1855 & 0 & 4 & 0 & 4 \\
\hline Hermodice carunculata (Pallas, 1766) & 4 & 0 & 8 & 0 \\
\hline \multicolumn{5}{|l|}{ CRUSTACEANS } \\
\hline Squilla cadenati Manning, 1970 & 4 & 22 & 4 & 186 \\
\hline Squilla mantis (Linnaeus, 1758) & 2 & 22 & 2 & 478 \\
\hline Solenocera africana Stebbing, 1917 & 2 & 22 & 3 & 2798 \\
\hline Sicyonia galeata Holthuis, 1952 & 14 & 22 & 25 & 542 \\
\hline Processa borboronica Holthuis, 1951 & 0 & 8 & 0 & 15 \\
\hline Parapandalus narval (Fabricius, 1787) & 3 & 11 & 31 & 76 \\
\hline Pontocaris cataphracta (Olivi, 1792) & 11 & 22 & 14 & 257 \\
\hline Scyllarus caparti Holthuis, 1952 & 26 & 22 & 273 & 4315 \\
\hline Scyllarus posteli Forest, 1963 & 26 & 22 & 1096 & 3925 \\
\hline Stenopus spinosus Risso, 1826 & 1 & 1 & 1 & 1 \\
\hline Paguristes mauritanicus Bouvier, 1906 & 26 & 21 & 593 & 164 \\
\hline Diogenes pugilator Roux, 1829 & 3 & 0 & 3 & 0 \\
\hline Diogenes ovatus Miers, 1881 & 21 & 19 & 80 & 76 \\
\hline Dardanus pectinatus (Ortmann, 1892) & 5 & 5 & 6 & 5 \\
\hline Pagunus mbizi Forest, 1955 & 25 & 20 & 95 & 57 \\
\hline Pagurus alatus Fabricius, 1775 & 24 & 21 & 70 & 40 \\
\hline Pagurus cuanensis Bell, 1846 & 12 & 9 & 15 & 13 \\
\hline Pagurus triangularis (Chevreux and Bouvier, 1892) & 3 & 6 & 3 & 6 \\
\hline Raninoides bouvieri Capart, 1951 & 1 & 15 & 1 & 27 \\
\hline Sternodromia spinirostris (Miers, 1881) & 4 & 22 & 6 & 161 \\
\hline Homola barbata Fabricius, 1793 & 5 & 8 & 5 & 10 \\
\hline Ethusa vossi Manning and Holthuis, 1981 & 3 & 1 & 4 & 1 \\
\hline Medorippe lanata (Linnaeus, 1767) & 26 & 22 & 341 & 1297 \\
\hline Calappa pelii Herklots, 1851 & 21 & 6 & 52 & 9 \\
\hline Atlantotlos rhombifer Doflein, 1904 & 3 & 1 & 3 & 1 \\
\hline Ilia spinosa Miers, 1881 & 2 & 11 & 2 & 19 \\
\hline Liocarcinus corrugatus (Pennant, 1777) & 1 & 7 & 1 & 10 \\
\hline Macropipus rugosus (Doflein, 1904) & 24 & 22 & 180 & 5427 \\
\hline Portunus inaequalis (Miers, 1881) & 1 & 1 & 1 & 1 \\
\hline Machaerus oxyacantha (Monod, 1956) & 4 & 10 & 4 & 15 \\
\hline Inachus leptochirus Leach 1817 & 3 & 0 & 3 & 0 \\
\hline Capartiella longipes (Capart, 1951) & 2 & 1 & 2 & 1 \\
\hline Macropodia gilsoni (Capart, 1951) & 3 & 2 & 3 & 2 \\
\hline Marcropodia spinusola (Miers, 1881) & 1 & 2 & 1 & 2 \\
\hline Stenorhynchus lanceolatus (Brullé, 1837) & 3 & 6 & 3 & 7 \\
\hline Parthenope notialis Manning and Holthuis, 1981 & 25 & 22 & 138 & 94 \\
\hline Heterocrypta maltzami Miers, 1881 & 1 & 0 & 1 & $\mathbf{0}$ \\
\hline \multicolumn{5}{|l|}{ MOLLUSCS } \\
\hline Calliostoma hernandezi Salazar and Gubbioli, 1993 & 8 & 10 & 11 & 13 \\
\hline Turritella annulata Kiener, 1853 & 9 & 6 & 12 & 7 \\
\hline Architectonica nobilis (Röding, 1798) & 2 & 2 & 2 & 2 \\
\hline Xenophora senegalensis Fischer, 1873 & 7 & 5 & 7 & 10 \\
\hline
\end{tabular}


Amex III. (continued).

\begin{tabular}{|c|c|c|c|c|}
\hline Species & Occurrence D & Occurrence $\mathrm{N}$ & Abundance D & Abundance $\mathbf{N}$ \\
\hline Natica canariensis Ohdner, 1931 & 2 & 0 & 2 & 0 \\
\hline Sigaretus bifasciatus Recluz, 1851 & 0 & 1 & 0 & 1 \\
\hline Cypraea petitiana Crosse, 1873 & 2 & 1 & 2 & 1 \\
\hline Phalium saburon Bruguière, 1792 & 1 & 16 & 1 & 39 \\
\hline Distorsio ridens (Reeve, 1884) & 12 & 16 & 16 & 23 \\
\hline Tonna galea Linnaeus, 1758 & 0 & 1 & 0 & 1 \\
\hline Murex cornutus Linnaeus, 1758 & 10 & 6 & 12 & 9 \\
\hline Murex rosarium Chemnitz, 1788 & 4 & 4 & 8 & 4 \\
\hline Murex varius Sowerby, 1834 & 5 & 1 & 6 & 1 \\
\hline Trophon fusulus (Brocchi, 1814) & 1 & 0 & 1 & 0 \\
\hline Phos grateloupianus Petit de la Saussaye, 1853 & 4 & 4 & 5 & 4 \\
\hline Metula cumingi Adams, 1858 & 4 & 3 & 4 & 3 \\
\hline Nassarius turbineus (Gould, 1845) & 7 & 3 & 8 & 3 \\
\hline Lathyrus filosus Schubert and Wagner, 1829 & 1 & 0 & 1 & 0 \\
\hline Fusus caparti Adam and Knudsen, 1955 & 1 & 0 & 1 & 0 \\
\hline Tudicla afra Gmelin, 1790 & 17 & 15 & 26 & 15 \\
\hline Cymbium patulum (Broderip, 1830) & 5 & 8 & 7 & 18 \\
\hline Cancellaria cancellata Linnaeus, 1767 & 6 & 5 & 10 & 5 \\
\hline Marginella cincta Kiener, 1834 & 0 & 6 & 0 & 6 \\
\hline Clavatula muricata (Lamarck, 1822) & 0 & 1 & 0 & 1 \\
\hline Clavatula diadema Kiener, 1841 & 22 & 15 & 51 & 32 \\
\hline Clavatula lelieuri (Recluz, 1851) & 13 & 9 & 18 & 11 \\
\hline Clavatula aculeiformis (Lamarck, 1822) & 0 & 1 & 0 & 1 \\
\hline Turris undatiruga (Bivona, 1832) & 2 & 2 & 2 & 2 \\
\hline Turris consociata (Smith, 1877) & 0 & 1 & 0 & 1 \\
\hline Genota mitraeformis (Wood, 1828) & 8 & 7 & 9 & 8 \\
\hline Terebra corrugata Lamarck, 1822 & 1 & $\mathbf{0}$ & 1 & 0 \\
\hline Philine aperta Linnaeus, 1767 & 15 & 10 & 64 & 61 \\
\hline Pleurobranchaea gela Marcus and Marcus, 1966 & 0 & 2 & 0 & 13 \\
\hline timbria fimbria (Linnaeus, 1767) & 0 & 1 & 0 & 1 \\
\hline Crassatella triquetra Reeve, 1842 & 4 & 5 & 4 & 5 \\
\hline Cardita umbonata Sowerby, 1904 & 1 & 0 & 1 & $\mathbf{0}$ \\
\hline \multicolumn{5}{|l|}{ ECHINODERMS } \\
\hline Antedon dubenii Bölsche, 1866 & 5 & 1 & 5 & 1 \\
\hline Astropecten irregularis Pennant, 1777 & 23 & 16 & 86 & 42 \\
\hline Astropecten jarli Madsen, 1950 & 2 & 0 & 2 & 0 \\
\hline Luidia atlantidea Madsen, 1950 & 1 & 0 & 1 & 0 \\
\hline Luidia heterozona Fisher, 1940 & 20 & 8 & 37 & 12 \\
\hline Luidia aciculata Mortensen, 1933 & 2 & 1 & 2 & 1 \\
\hline Centrostephanus longispinus (Philippi, 1845) & 3 & 5 & 3 & 8 \\
\hline Genocidaris maculata A. Agassiz, 1869 & 3 & 3 & 3 & 3 \\
\hline Schizaster edwardsi Cotteau, 1889 & 24 & 20 & 109 & 73 \\
\hline Rhopalodina gracilis Panning, 1936 & 1 & $\mathbf{0}$ & 1 & 0 \\
\hline \multicolumn{5}{|l|}{ BRYOZOANS } \\
\hline Cupuladria canariensis (Busk, 1859) & 22 & 20 & 89 & 89 \\
\hline Hippoporidra senegambiensis (Carter, 1882) & 19 & 17 & 92 & 74 \\
\hline
\end{tabular}

